Article

\title{
Infrared Thermography: A Method to Visualise and Analyse Sulphide Oxidation
}

\author{
Marjan Knobloch *(i) and Bernd G. Lottermoser(D) \\ Institute of Mineral Resources Engineering, RWTH Aachen University, Wüllnerstrasse 2, 52062 Aachen, Germany; \\ lottermoser@mre.rwth-aachen.de \\ * Correspondence: knobloch@mre.rwth-aachen.de; Tel.: +49-241-8095670
}

Received: 12 August 2020; Accepted: 20 October 2020; Published: 22 October 2020

check for

updates

\begin{abstract}
Environmental testing of sulphidic ores and wastes aims to assess the release of metals and metalloids at acid $\mathrm{pH}$ conditions and the samples' likelihood to produce acid rock drainage (ARD). However, the majority of established ARD tests measure geochemical properties of samples and cannot visualise the exothermic oxidation reactions and their intensity leading to metalliferous drainage in all $\mathrm{pH}$ environments. This paper proposes a new protocol to detect and visualise the sulphide oxidation in ores and wastes. Six nearly monomineralic sulphides were crushed, sieved to two size fraction (0.09-4 mm), milled to powder and treated with $\mathrm{H}_{2} \mathrm{O}_{2}$. The thermal energy released upon sulphide oxidation was optically detected and temperatures measured using a portable infrared thermographic camera. Based on temperature-time progression curves, the oxidation reactivity of sulphides was derived from high to low: chalcopyrite $>$ arsenopyrite $>$ pyrite $>$ sphalerite $>$ stibnite $>$ galena, which depends on grain size, amount of sulphides and other non-sulphide mineral phases present in the sample material. The study demonstrates that the application of $\mathrm{H}_{2} \mathrm{O}_{2}$ to sulphide sample powders and subsequent visualisation of the treated materials using a thermographic camera represents a rapid technique in revealing the presence of oxidising sulphides under all $\mathrm{pH}$ conditions.
\end{abstract}

Keywords: thermal imaging; thermographic camera; acid rock drainage; metalliferous drainage; hydrogen peroxide; leaching; pyrite

\section{Introduction}

Modern mineral resources development necessitates a comprehensive deposit knowledge from the beginning of life-of-mine, which involves the reliable understanding of all the relevant characteristics of a mineral resource including its environmental properties [1]. To date, environmental characterisation has largely focused on the prediction of acid rock drainage (ARD) using geochemical tools [2]. Such geochemical tools are routinely used in ARD risk assessments of ores, mine wastes and mine workings. In fact, numerous chemical static and kinetic tests exist to evaluate the acid producing potential of materials. Based on these tests, risk assessments and waste classification schemes can be developed and devised [2]. However, these proven and commonly used tests and methods have intrinsic limitations, discussed and mentioned by Parbhakar-Fox and Lottermoser [2]: (i) kinetic test data are not always produced until much later during mine development; (ii) best practices on sampling processes are not always applied; (iii) static tests are conducted off-site and hence do not reflect the real field conditions; (iv) ARD assessments are carried out on the basis of static and kinetic tests, but these can provide limited data and results, if the ARD tests are used for samples whose characteristics do not correspond with the sample characteristics the ARD tests were originally designed for leadings to deviations in the accuracy of waste classifications and block models; and (v) waste classification schemes often do not consider other drainage forms (e.g., neutral metalliferous, saline or As-Sb-rich waters) [2-5]. As a result of this, the reliable implementation of ARD prediction is both demanding 
and difficult. New and improved approaches for mine water quality prediction need to consider these missing parameters, and there is a need for tests that provide insights into metalliferous drainage regardless of $\mathrm{pH}$. Furthermore, mining professionals, who are responsible for operational processes and waste monitoring, require rapid information on waste and water quality risks to allow for the preparation of comprehensive environmental impact assessments and to achieve highest certainty for well-informed decisions in mine waste management.

IR and pXRF instruments yield information on existing mineralogical compositions by measuring total metal and metalloid concentrations of ores and wastes, but data acquired with these instruments do not allow the deduction of sulphides. Commonly used methods of mineral identification and analysis include visual descriptions, petrographic analyses (thin section or polished blocks), X-ray diffraction (XRD), scanning electron microscope spectroscopy (SEM), energy dispersive spectroscopy (EDS), electron microprobe (EM), QEMSCAN and mineral liberation analysis (MLA); the latter four are frequently used to answer specific mineralogical questions. The laboratory-based powder X-ray diffraction (XRD) techniques cannot detect sulphide minerals within samples, unless the sulphide minerals occur at several $w t \%$ within the analysed materials. The Global Acid Rock Drainage (GARD) Guide [6] further states that the provision of only qualitative or semiquantitative data and the small sample volume for analysis can lead to important trace amounts of minerals not being detected in mineralogical analysis. Key and relevant minor and trace elements might also occur as impurities instead of major structural elements. Variations in the minerals chemistry (solid solutions) are difficult to detect and greatly affects the stability, weatherability, oxidation rate and contribution to the drainage chemistry [6].

Rapid field-based characterisation tests of sulphidic ores and wastes are available, for example, the single addition net acid generation (NAG) test; paste $\mathrm{pH}, \mathrm{EC}$ and USGS field leach tests (FLT); carbonate staining techniques; wall washing; and portable X-ray fluorescence (pXRF) for geochemical analyses [2,7]. Total contents of sulphur and carbon, which are used to calculate the acid potential (AP) and neutralising potential (NP), are usually determined using inductively coupled plasma atomic emission spectrometry (ICP-AES) [8,9] or infrared absorption spectrometry (IRAS) to analyse the evolved gas caused by the combustion of the sample material $[10,11]$. However, the AP and NP calculation are highly error-prone and can lead to overestimations, underestimations or inaccurate results, because of (i) using stoichiometric standard factors, (ii) carbonate minerals which do not lead to neutralisation are erroneously considered as neutralising (e.g., siderite, $\mathrm{FeCO}_{3}$ and ankerite $\left.\mathrm{Ca}(\mathrm{Fe}, \mathrm{Mg}) \mathrm{CO}_{3}\right)$, (iii) solution of non-carbonate minerals which can increase the rate of neutralisation are excluded (e.g., Na- and K-bearing silicates), (iv) not all sources of Fe-protons that can contribute to acid formation are taken into account (e.g., Fe-hydroxides, Fe-sulphates), (v) if the sample material contains excessively concentrations of non-acid forming sulphur and (vi) no consideration given to differing particle sizes [12-22]. Furthermore, $\mathrm{pH}$ tests are particularly useful for assessing the chemistry of first flush waters draining sulphidic rocks and wastes [23]. However, all these field tests measure existing conditions and cannot be used to predict future water quality. NAG tests can provide information about the future water quality, but these tests are also prone to errors [19], especially the NAG pH. First, a sufficient quantity of carbonate minerals can lead to a neutralisation of the released acid and consequently to neutral $\mathrm{pH}$. Due to this neutral $\mathrm{pH}$, potential sulphide reactions can be undetected, leading to erroneous assessments of the environmental risk if the samples are rich sulphides, that contain harmful metalloids which are also mobile under neutral pH, e.g., As or Sb. Second, the incomplete oxidation of sulphide minerals during NAG testing can lead to a neutral $\mathrm{pH}$ if adequate amounts of acid-consuming minerals are available to neutralise the acid released [19]. Moreover, an overestimation of the acidification potential during the NAG pH test is possible, due to the formation of organic acid, which leads to acid $\mathrm{pH}$ if the modified NAG (m-NAG) test is not used [24]. Detailed information and variations of NAG testing is provided in the AMIRA ARD Test Handbook [25]. Thus, current field techniques do not allow a rapid recognition and quantification of sulphide minerals in rocks, ores and wastes. However, a sound knowledge on the presence and likely 
abundance of sulphide minerals is crucial in mine waste management. When sulphide minerals are exposed to oxygen, the reactions release large amounts of acid, metals and metalloids as well as heat [26-29].

In this study, a newly designed test protocol and procedure has been developed based on the application of hydrogen peroxide $\left(\mathrm{H}_{2} \mathrm{O}_{2}\right)$ to sulphidic samples and subsequent measurement of the temperature changes and visualisation of the heat release of treated samples using infrared thermography. The measurement of temperatures during the reaction between sulphides and $\mathrm{H}_{2} \mathrm{O}_{2}$ has been documented in kinetic NAG tests in other studies before [19,20,29-33] but has never received much attention or significance until now. In previous studies, temperatures were measured in a single point using a thermometer. Subsequent results regarding the reactivity of the sulphide minerals were not described in depth, discussed or used in environmental studies. The present study aims to show the potential of time-temperature-progression curves produced in the course of the sulphide- $\mathrm{H}_{2} \mathrm{O}_{2}$ reaction and to document and demonstrate its usefulness for the adaptation of environmental issues. The test protocol aims to be easy, rapid and cheap, and it is carried out in the field to get a quick overview of the sample material and to improve the initial estimate regarding the presence of sulphides and their oxidation reactivity and support the representative sample selection for further static and kinetic laboratory tests. Consequently, this contribution adds to existing testing methods for sulphidic rocks, ores and wastes, and it makes recommendations on the use of this newly designed optical method in environmental risk assessments at exploration and mine sites.

\section{Materials and Methods}

\subsection{Samples and Sample Processing}

To develop the infrared thermographic test protocol (IR), selected mineral specimens were obtained from commercial mineral dealers, including pyrite $\left(\mathrm{FeS}_{2}\right.$, Huanzala Mine, Peru), chalcopyrite $\left(\mathrm{CuFeS}_{2}\right.$, Piendras Verdes Mine, Mexico), arsenopyrite (FeAsS, Ehrenfriedersdorf, Germany), sphalerite (ZnS, Aguilar mine, Argentinia), galena (PbS, Stribro, Czech Republic), stibnite $\left(\mathrm{Sb}_{2} \mathrm{~S}_{3}\right.$, Podkozara, Bosnia-Herzegovina), calcite $\left(\mathrm{Ca}\left[\mathrm{CO}_{3}\right]\right.$, Flandersbach, Germany) and quartz $\left(\mathrm{SiO}_{2}\right.$, Lausitz, Germany). Samples were dried, crushed, sieved to two size fractions (0.09-2 and $2-4 \mathrm{~mm}$ ) and also milled to powder using a vibration disc and tungsten carbide ring mill. Sample materials were used for Net Acid Generation $\mathrm{pH}(\mathrm{NAGpH})$, X-ray diffraction (XRD) analyses and the new developed infrared thermographic (IR) visualisation method.

\subsection{Mineralogical and Geochemical Analyses}

The mineralogy of all sulphide, calcite and quartz samples was confirmed using the X'Pert PRO diffractometer of PANalytical. The diffractometer was operating in $\Theta-\Theta$-geometry, ran with a ceramic $\mathrm{CuK} \alpha \mathrm{X}$-ray tube (20 W) and a detector (PIXcel) measurement setting of $40 \mathrm{kV}$ and $50 \mathrm{~mA}$. The results were evaluated both qualitatively, using the X'Pert Highscore software (PANalytical, Malvern, UK), and semiquantitatively, using the Reference Intensity Ratio (RIR), normalised to $100 \%$ crystalline materials.

The geochemistry of the sulphide monominerals was analysed using the portable Olympus Vanta VCA X-ray analyser (Olympus, Tokyo, Japan), which is equipped with a silicon drift detector (SSD), an Ag anode at $50 \mathrm{kV}$ 4W X-ray tube and a Kapton-Mesh-Prolene window, operated in "GeoChem" mode with three integrated beams for high $(50 \mathrm{kV})$, medium $(40 \mathrm{kV})$ and low $(10 \mathrm{kV})$ excitation energy for optimal detection of light and heavy elements. Each sample was measured five times, $30 \mathrm{~s}$ for each beam, followed by determination of the average element concentrations, precision, accuracy and lower detection limits (LODs, $3 \sigma$ standard deviation mean). The certified reference materials (CRMs) NIST 2711A, OREAS 131b, OREAS 132b, OREAS 133b, OREAS 134b, OREAS 235 and MP-1b-966-23 as well as two $\mathrm{SiO}_{2}$ blanks were used for data quality control.

A single additional NAGpH test was performed to determine the acid generating potential of all powdered test samples [25]. For this, $250 \mathrm{~mL}$ of $15 \% \mathrm{H}_{2} \mathrm{O}_{2}$ was mixed with $2.5 \mathrm{~g}$ powdered sample 
material in a beaker and allowed to react for $24 \mathrm{~h}$. This was followed by measuring the $\mathrm{pH}$ and $\mathrm{Eh}$ values with a pH/ORP meter HI 991002 of Hanna Instruments Ltd (Bedfordshire, UK). The instrument's pH calibration was based on the manufacturer's buffer solutions HI7007 ( $\mathrm{pH}=7$ ) and HI7004 (pH = 4). Afterwards, the samples were moderately heated to accelerate oxidation of any remaining sulphides until no further reaction could be observed. After cooling down, the $\mathrm{pH}$ values were measured again. The heating-cooling cycle was repeated on samples consisting of 50\% (1.25 g) sulphide minerals and $50 \%$ calcite $(1.25 \mathrm{~g})$, to illustrate the change of NAGpH values due to the presence of carbonate.

\subsection{Infrared Thermography Method}

The aim of the testing protocol was to induce and accelerate the exothermic oxidation of sulphide minerals and to visualise any heat release from the induced chemical reactions. The rationale was pursued by (1) inducing and accelerating the exothermic oxidation of sulphide minerals first using a hydrogen peroxide solution and (2) measuring the surface temperature and imaging the thermal energy release using a thermographic camera (FLIR T650sc, FLIR Systems, Wilsonville, Clackamas County, OR, USA). The FLIR camera is equipped with an uncooled Vanadium Oxide (VOx) microbolometer detector (FLIR Systems, Wilsonville, Clackamas County, OR, USA) that produces thermal images of $640 \times 480$ pixels. Its spectral range is at 7.5 to $14 \mu \mathrm{m}$ and its accuracy is given as $\pm 1{ }^{\circ} \mathrm{C}$ or $\pm 1 \%$ of reading temperature ranges of objects within $5{ }^{\circ} \mathrm{C}$ to $120^{\circ} \mathrm{C}$ at ambient temperatures of $10^{\circ} \mathrm{C}$ to $35^{\circ} \mathrm{C}$.

In a pilot study, various experimental arrangements were tested. In the first attempt, hydrogen peroxide solutions of different concentrations (3\% to 30\%) were applied using a paint brush to sulphidic minerals. Subsequently, attempts were made to catalyse any exothermic reactions by (1) roughening the sample surface using a diamond hand-grinder (grit 50 and 400), (2) heating the samples in an oven $\left(40{ }^{\circ} \mathrm{C}\right)$ and (3) using catalase and iron(III) chloride solutions.

Following the pilot study, dried samples of two size fractions (0.09-2 and 2-4 mm) and powders were produced, and a representative $5 \mathrm{~g}$ aliquot was accurately weighed into a $500 \mathrm{~mL}$ cylindrical beaker. A smaller beaker (e.g., $250 \mathrm{~mL}$ ) is also possible, but this is not recommended for safety reasons, as highly reactive samples can boil over. The initial temperature $\left(T_{\text {start }}\right)$ of each sample was then determined using the FLIR T650sc camera, which was mounted on a tripod and placed a sufficient distance above the sample to ensure the camera was not damaged by the reaction. Subsequently, $50 \mathrm{~mL}$ of $12 \% \mathrm{H}_{2} \mathrm{O}_{2}$ was added to the beaker at room temperature, and the first reaction temperature was recorded immediately $\left(T_{0}\right)$ using the FLIR camera. The use of a higher concentration than $12 \%$ $\mathrm{H}_{2} \mathrm{O}_{2}$ is not recommended for safety reasons, as strongly reactive samples can boil over or strong vapour formation can occur. During the first $15 \mathrm{~min}$ of reaction time, the temperature was recorded every minute $\left(T_{1}\right.$ to $\left.T_{15}\right)$. After this, the time interval for subsequent temperature measurements was increased to $5 \mathrm{~min}\left(T_{15+5}\right)$. Monitoring of the reaction temperatures $\left(T_{x}\right)$ continued until the peak temperature was reached and the temperature cooled to the initial temperature $\left(T_{\text {start }}\right)$ again. If no peak temperature was reached, followed by a temperature decrease, the measurement was stopped after either $90 \mathrm{~min}$ or $120 \mathrm{~min}$. The FLIR 650sc camera has a self-timer mode for automatic image shots. No photos or data needed to be recorded manually. Direct sunlight can cause reflections on the sample surface or the edge of the beaker glass [34]. The IR camera measures the temperatures on the sample surface and consequently, surface reflections can lead to a misinterpretation of the results, if they go unnoticed. Therefore, it is advisable to perform the tests out of direct sunlight, use shields and to define a measuring window in the camera settings. The temperatures measured by the thermal imaging camera were verified using the digital thermometer from the pH/ORP meter HI 991002 of Hanna Instruments Ltd., which was also used for the NAGpH test. It measures temperatures in liquids in a range from $5{ }^{\circ} \mathrm{C}$ to $105^{\circ} \mathrm{C}$ with a resolution of $0.1{ }^{\circ} \mathrm{C}$ and accuracy of $\pm 0.5{ }^{\circ} \mathrm{C}\left(<60{ }^{\circ} \mathrm{C}\right)$ and of $\pm 1^{\circ} \mathrm{C}\left(>60^{\circ} \mathrm{C}\right)$, respectively.

From the acquired data, the highest recorded temperature $\left(T_{\max }\right)$, the time taken to reach the maximum temperature $\left(t_{\max }\right)$ and the total reaction time $\left(t_{\text {total }}\right)$ were established. 
In addition, the difference between the maximum temperature $\left(T_{\max }\right)$ and the initial temperature $\left(T_{\text {start }}\right)$ were used to calculate the absolute temperature increase $\left(T_{\text {diff }}\right)$ :

$$
T_{\text {diff }}=T_{\text {max }}-T_{\text {start }}
$$

The latter experimental parameters $\left(T_{\text {start }}, T_{\max }, T_{\text {diff }}, t_{\text {total }}\right)$ allowed interpretations about possible exothermic oxidation reactions of sulphides and therefore the reactivity of the investigated samples. All parameters are listed in Table 1.

Table 1. List of parameters recorded during IR thermography testing.

\begin{tabular}{cl}
\hline Parameter & \multicolumn{1}{c}{ Description } \\
\hline$T_{\text {start }}$ & Initial temperature of the sample material \\
$T_{0}$ & First reaction temperature; recorded immediately after the addition of $50 \mathrm{~mL}$ of $12 \% \mathrm{H}_{2} \mathrm{O}_{2}$ \\
$T_{x}$ & Reaction temperature of the indicated minute \\
$T_{\max }$ & Highest recorded temperature \\
$T_{\text {diff }}$ & Absolute temperature increase; difference between the maximum temperature $\left(T_{\max }\right)$ and \\
$t_{\max }$ & the initial temperature $\left(T_{\text {start }}\right)$ \\
$t_{\text {total }}$ & Time taken to reach the maximum temperature $\left(T_{\max }\right)$ \\
\hline
\end{tabular}

In addition, pyrite was mixed with calcite in nine different proportions (90:10 to 0.1:99.9 pyrite:calcite) as well as with quartz (down to 0.1:99.9 pyrite:quartz), and these materials were treated with hydrogen peroxide and investigated using the described IR protocol. Different sulphide:calcite and sulphide:quartz proportions were chosen to evaluate whether acid-neutralising minerals like calcite influence the heat releases over time and resultant temperature-time curves. Finally, in order to investigate whether pyrite is partially or completely destroyed upon a single hydrogen peroxide addition, already reacted and cooled down pyrite samples were treated again with $50 \mathrm{~mL}$ of $12 \% \mathrm{H}_{2} \mathrm{O}_{2}$, and the temperature-time profiles were recorded.

\section{Results}

\subsection{Sample Characteristics}

XRD analysis confirmed the identity of sulphide minerals, calcite and quartz chosen for this study (Table 2). Samples are either monomineralic or nearly monomineralic materials. The metal and metalloid concentrations of interest of all sulphide minerals are reported in Table 3 . The corresponding accuracies, precisions and LODs are given in Supplementary Table S1. Of particular relevance and interest for this study are Fe concentrations in the non-ferrous sulphides. Sphalerite used in this study is rich in iron (7.62 wt\%, Table 3). Significant but lower Fe contents were detected for stibnite (0.05 wt \%, Table 3). No impurities of Fe but elevated concentrations of As (33,360 ppm) could be analysed in galena (Table 3). Other metal and metalloid trace elements detected with a concentration of less than $1 \mathrm{wt} \%(\mathrm{Ag}, \mathrm{Cd}, \mathrm{Cr}, \mathrm{Co}, \mathrm{Mn}, \mathrm{Mo}, \mathrm{Ni}, \mathrm{Sn}$ and $\mathrm{W})$ are given in Table 3. All sulphide samples produced NAGpH solutions with an acid pH (Figure 1). Stibnite produced the most acid solution $(\mathrm{pH}=1.97 ; \mathrm{Eh}=505 \mathrm{mV})$ in contrast to sphalerite, which generated the most weakly acid eluate of all sulphides $(\mathrm{pH}=4.45 ; \mathrm{Eh}=380 \mathrm{mV})$. In general, sulphides, when mixed 50:50 with calcite, generated alkaline waters but all boiled solutions showed higher $\mathrm{pH}$ values $(\mathrm{pH}=7.19-7.55$; $\mathrm{Eh}=258-304 \mathrm{mV})$ compared to non-boiled solutions ( $\mathrm{pH}=6.8-6.97$; Eh $=206-281 \mathrm{mV}$ ). Boiling these carbonate-rich eluates, as prescribed in the NAGpH test protocol to accelerate remaining sulphides [25], leads to alkaline $\mathrm{pH}$ values (Figure 1) due to the dissolution of carbonate minerals during the NAGpH test and the formation of $\mathrm{Ca}(\mathrm{OH})_{2}$ [2,35]. To complete data acquisition, the NAGpH test was also performed on pure calcite (Figure 1), yielding a $\mathrm{pH}$ of $7.6(\mathrm{Eh}=253 \mathrm{mV})$ and $8.2(\mathrm{Eh}=223 \mathrm{mV})$ before and after boiling, respectively. 
Table 2. Mineralogy of samples as determined by XRD.

\begin{tabular}{|c|c|c|}
\hline Sample & Material & Content (wt $\%)$ \\
\hline 1 & Chalcopyrite $\left(\mathrm{CuFeS}_{2}\right)$ & 100 \\
\hline 2 & Galena (PbS) & 100 \\
\hline \multirow{3}{*}{3} & Sphalerite (ZnS) & 91 \\
\hline & Galena $(\mathrm{PbS})$ & 8 \\
\hline & Quartz $\left(\mathrm{SiO}_{2}\right)$ & 1 \\
\hline \multirow{4}{*}{4} & Pyrite $\left(\mathrm{FeS}_{2}\right)$ & 85 \\
\hline & Rhomboclase & 12 \\
\hline & $\left(\mathrm{H}_{5} \mathrm{Fe}_{3}+\mathrm{O}_{2}\left(\mathrm{SO}_{4}\right)_{2} \cdot 2\left(\mathrm{H}_{2} \mathrm{O}\right)\right.$ & 12 \\
\hline & $\begin{array}{l}\text { Szomolnokite } \\
\left(\mathrm{Fe}_{2}+\mathrm{SO}_{4} \cdot \mathrm{H}_{2} \mathrm{O}\right)\end{array}$ & 3 \\
\hline \multirow{2}{*}{5} & Stibnite $\left(\mathrm{Sb}_{2} \mathrm{~S}_{3}\right)$ & 81 \\
\hline & Quartz $\left(\mathrm{SiO}_{2}\right)$ & 19 \\
\hline \multirow{5}{*}{6} & Arsenopyrite $\left(\mathrm{FeS}_{2}\right)$ & 69 \\
\hline & Szomolnokite & \\
\hline & $\left(\mathrm{Fe}_{2}+\mathrm{SO}_{4} \cdot \mathrm{H}_{2} \mathrm{O}\right)$ & 20 \\
\hline & Siderite $\left(\mathrm{FeCO}_{3}\right)$ & 5 \\
\hline & Quartz $\left(\mathrm{SiO}_{2}\right)$ & 6 \\
\hline 7 & Calcite $\left(\mathrm{CaCO}_{3}\right)$ & 100 \\
\hline 8 & Quartz $\left(\mathrm{SiO}_{2}\right)$ & 100 \\
\hline
\end{tabular}

Table 3. Sulphide minerals geochemistry of significant metals and metalloids determined by pXRF.

\begin{tabular}{cccccccc}
\hline Sample & $\begin{array}{c}\mathbf{F e} \\
(\mathbf{w t} \mathbf{\%})\end{array}$ & $\begin{array}{c}\mathbf{C u} \\
(\mathbf{p p m})\end{array}$ & $\begin{array}{c}\mathbf{P b} \\
(\mathbf{p p m})\end{array}$ & $\begin{array}{c}\mathbf{Z n} \\
(\mathbf{p p m})\end{array}$ & $\begin{array}{c}\mathbf{A s} \\
(\mathbf{p p m})\end{array}$ & $\begin{array}{c}\mathbf{S b} \\
(\mathbf{p p m})\end{array}$ & Other Trace Elements ( $\leq \mathbf{1 0 0 0} \mathbf{p p m})$ \\
\hline Pyrite & 42.13 & 143 & 132 & 71 & 280 & 79 & $\mathrm{Co}$ \\
Chalcoyprite & 20.20 & 347,800 & $<8$ & 2020 & $<3$ & 131 & $\mathrm{Ag}, \mathrm{Co}$ \\
Arsenopyrite & 20.62 & 174 & $<4$ & 89 & 402,700 & 266 & $\mathrm{Co}, \mathrm{Cr}, \mathrm{Sn}, \mathrm{W}$ \\
Stibnite & 0.05 & 77 & 74 & $<3$ & 138 & 508,000 & $\mathrm{Cd}$ \\
Sphalerite & 7.62 & 736 & 61,700 & 502,300 & 3240 & 180 & $\mathrm{Ag}, \mathrm{Cd}, \mathrm{Cr}, \mathrm{Mn}(16,000 \mathrm{ppm}), \mathrm{Mo}, \mathrm{Ni}$, \\
Galena & $<0.002$ & 284 & 556,300 & 1067 & 33,360 & 990 & $\mathrm{Cr}, \mathrm{Ni}, \mathrm{W}$ \\
\hline
\end{tabular}

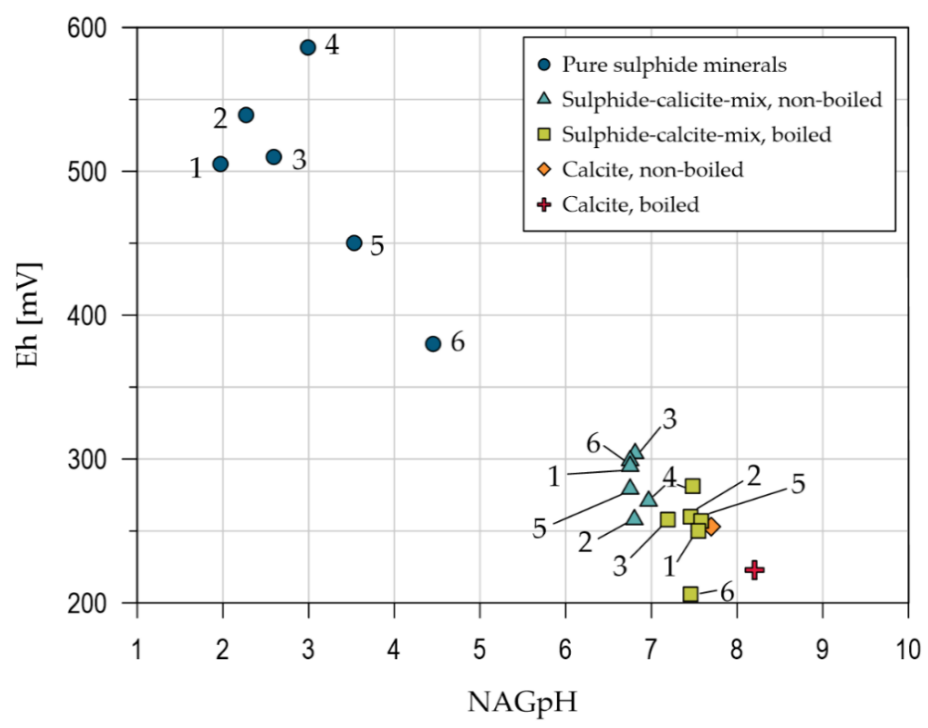

Figure 1. NAGpH versus Eh $(\mathrm{mV})$ data for monomineralic and polymineralic samples tested by this study. 1 = stibnite; 2 = pyrite $3=$ arsenopyrite $4=$ chalcopyrite $5=$ galena $; 6=$ sphalerite. 


\subsection{Infrared Thermography}

\subsubsection{Pilot Study}

In a pilot study, various experimental arrangements were tested. In the first attempt, hydrogen peroxide solutions of different concentrations ( $3 \%$ to $30 \%$ ) were applied using a paint brush to sulphide minerals (Figure 2). However, no heat release could be observed using the FLIR T650sc camera. This could have been due to insufficient quantities of the hydrogen peroxide solution applied to relatively small surface areas and associated evaporative cooling. Moreover, no heat release could be detected using the thermal imaging camera, when heating the samples in an oven $\left(40^{\circ} \mathrm{C}\right.$, Supplementary Figure S1) and using catalase and iron(III) chloride solutions as catalysts (Supplementary Figure S2).

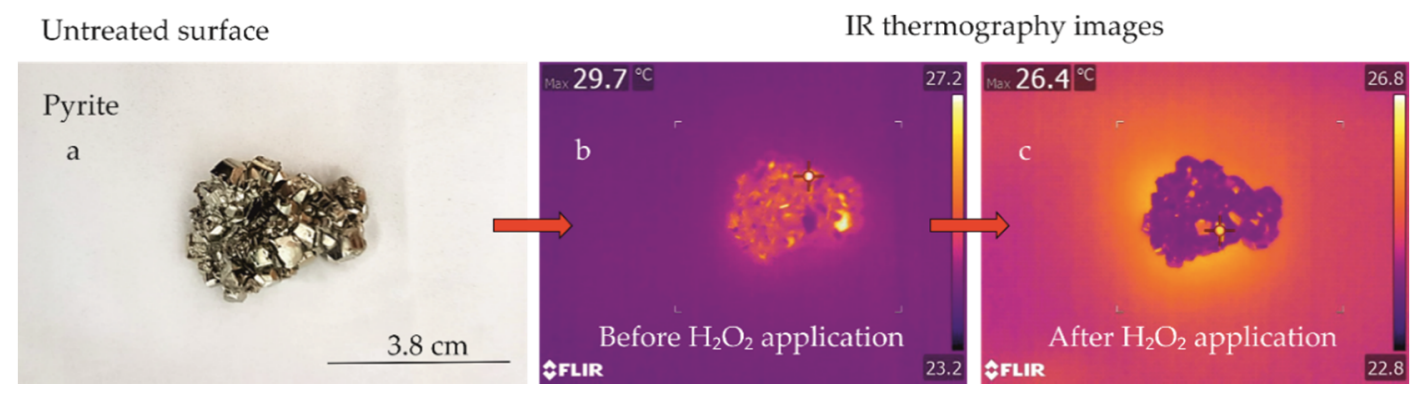

Figure 2. (a) Picture of untreated pyrite prior to treatment. (b,c) IR thermography images of pyrite before and after the application of the $30 \% \mathrm{H}_{2} \mathrm{O}_{2}$ solution to the pyrite surface. The maximum temperature measured and temperature distribution across the images are also shown.

Subsequently, attempts were made to catalyse any exothermic reactions by roughening the sample surface using a diamond hand-grinder (grit 50 and 400; Supplementary Figure S3). Such roughing of sample surfaces led to a detectable heat release. Yet, after careful observation, it was established that the roughened surface itself had not reacted with the hydrogen peroxide, but the fine-grained particles of the sample material produced during roughening. This clearly demonstrated that an increase of the reaction surface area was necessary to measure changes in surface temperatures and to capture a possible heat release with the IR camera. These observations led to the decision to mill the mineral samples for subsequent IR investigations.

\subsubsection{Thermography Method}

Thermographic measurements of the powdered and sieved mineral samples treated with hydrogen peroxide show significant temperature changes over time. These progressive changes in heat release have been illustrated for the different mineral samples in temperature-time curves (Figures 3a and 4a, Supplementary Figures S4a-S7a). Essential parameters for the evaluation and interpretation of the thermographic test results are listed in Table 4. Raw data of IR-measurements are available in Supplementary Table S2. 

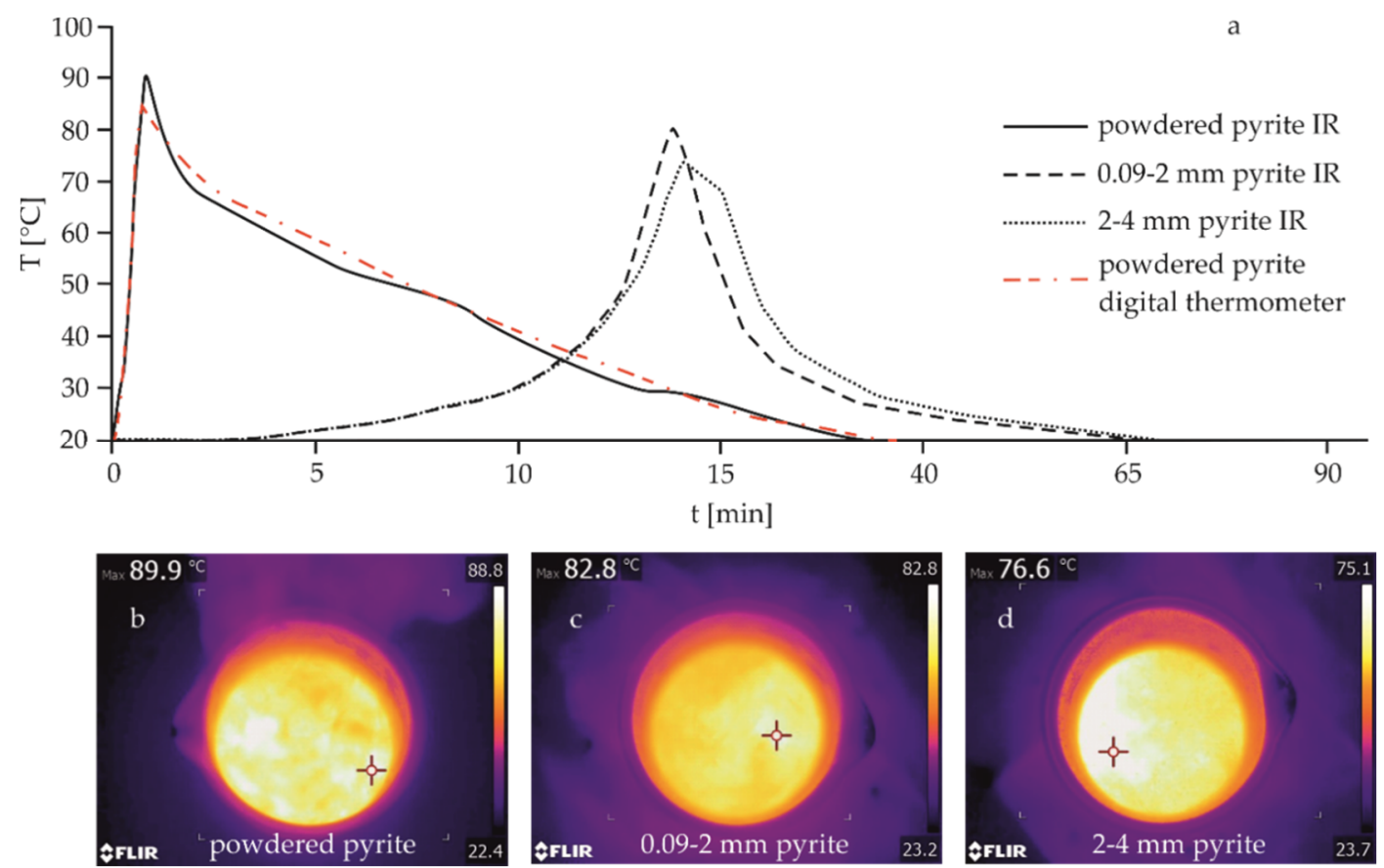

Figure 3. (a) Temperature-time graphs for powdered and sieved pyrite samples as measured using the IR camera and a digital thermometer. (b-d) IR thermography images of the temperature maxima $\left(T_{\max }\right)$ for the powdered and sieved pyrite samples as measured using the IR camera.
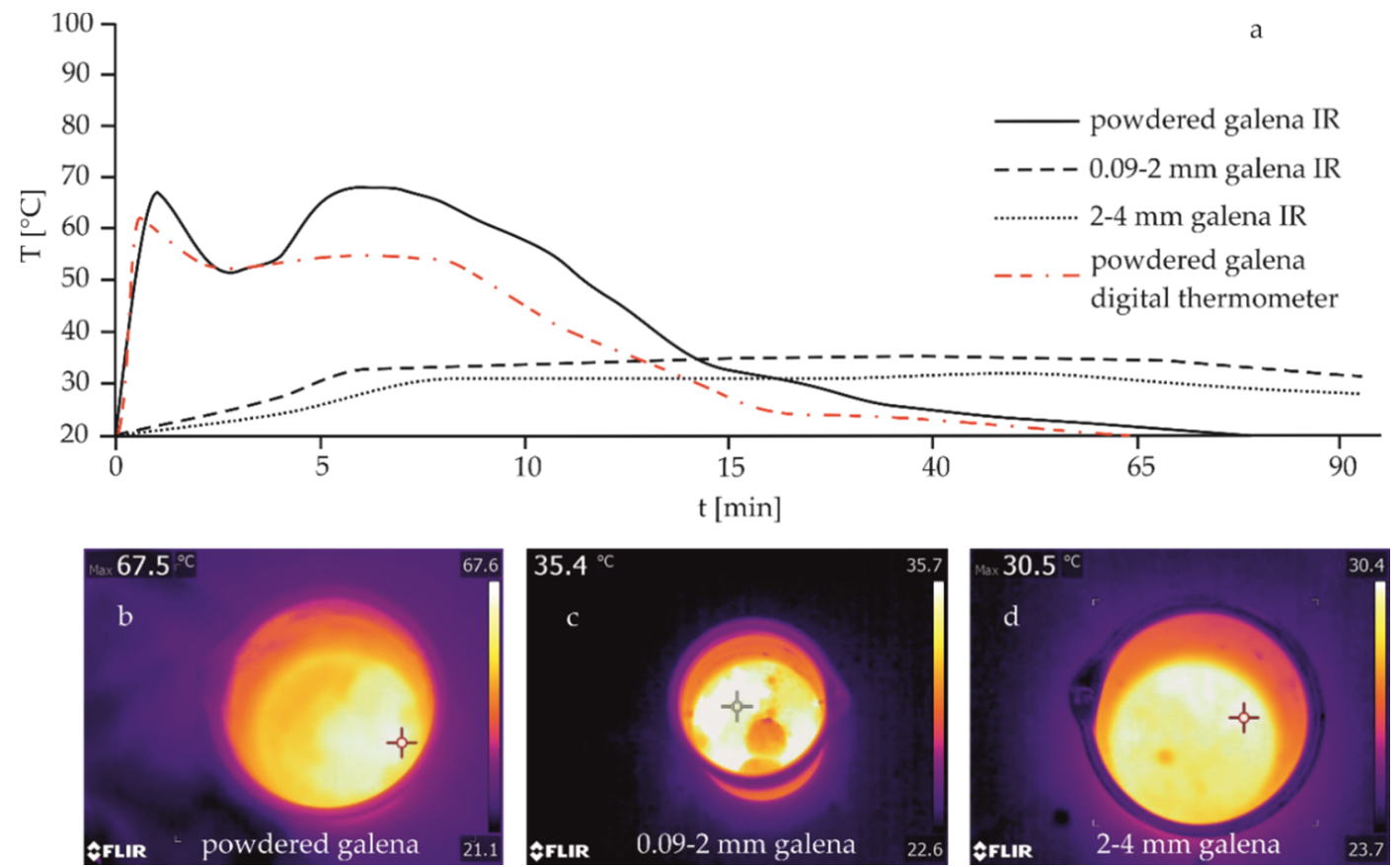

Figure 4. (a) Temperature-time graphs for powdered and sieved galena samples as measured using the IR camera and a digital thermometer. (b-d) IR thermography images of the temperature maxima $\left(T_{\max }\right)$ for the powdered and sieved galena samples as measured using the IR camera. 
Table 4. List of temperature and time parameters that were recorded for the various size fractions of sulphide minerals during IR thermography testing (maximum temperature, $T_{\max }$ ); time to reach the maximum temperature, $t_{\max }$; calculated temperature difference, $T_{\text {diff; }}$ total reaction time, $t_{\text {total }}$ ). Reactions that lasted longer than 90 min were terminated after this time (>90).

\begin{tabular}{|c|c|c|c|c|c|c|}
\hline Mineral & $\begin{array}{l}\text { Fraction Size } \\
(\mathrm{mm})\end{array}$ & $\begin{array}{l}T_{\max } \\
\left({ }^{\circ} \mathrm{C}\right)\end{array}$ & $\begin{array}{c}t_{\max } \\
(\min )\end{array}$ & $\begin{array}{l}T_{\text {diff }} \\
\left({ }^{\circ} \mathrm{C}\right)\end{array}$ & $\begin{array}{l}t_{\text {total }} \\
\text { (min) }\end{array}$ & Corresponding Figure \\
\hline \multirow{3}{*}{ Pyrite } & powdered & 89.9 & 1 & 69.8 & 30 & Figure $3 a$ \\
\hline & $0.09-2$ & 82.8 & 13 & 62.8 & 65 & Figure $3 b$ \\
\hline & $2-4$ & 76.6 & 14 & 56.4 & 70 & Figure $3 c$ \\
\hline \multirow{3}{*}{ Galena } & powdered & 67.5 & 1 & 47.6 & 75 & Figure $4 \mathrm{a}$ \\
\hline & $0.09-2$ & 35.4 & 20 & 15.2 & $>90$ & Figure $4 b$ \\
\hline & $2-4$ & 30.5 & 45 & 10.3 & $>90$ & Figure $4 c$ \\
\hline \multirow{3}{*}{ Chalcopyrite } & powdered & 89.6 & 2 & 69.6 & 50 & Supplementary Figure S4a \\
\hline & $0.09-2$ & 66.2 & 75 & 45.9 & $>90$ & Supplementary Figure S4b \\
\hline & $2-4$ & 21.5 & $>90$ & 1.5 & $>90$ & Supplementary Figure S4c \\
\hline \multirow{3}{*}{ Arsenopyrite } & powdered & 83.3 & 1 & 63.0 & 45 & Supplementary Figure S5a \\
\hline & $0.09-2$ & 24.4 & $>90$ & 4.3 & $>90$ & Supplementary Figure S5b \\
\hline & $2-4$ & 20.9 & $>90$ & 0.6 & $>90$ & Supplementary Figure S5c \\
\hline \multirow{3}{*}{ Stibnite } & powdered & 87.9 & 1 & 67.8 & 70 & Supplementary Figure S6a \\
\hline & $0.09-2$ & 24.3 & $>90$ & 4.4 & $>90$ & Supplementary Figure S6b \\
\hline & $2-4$ & 21.1 & $>90$ & 1.1 & $>90$ & Supplementary Figure S6c \\
\hline \multirow{3}{*}{ Sphalerite } & powdered & 87.9 & 2 & 67.8 & 55 & Supplementary Figure S7a \\
\hline & $0.09-2$ & 28.1 & $>90$ & 7.9 & $>90$ & Supplementary Figure S7b \\
\hline & $2-4$ & 23.7 & $>90$ & 3.4 & $>90$ & Supplementary Figure S7c \\
\hline
\end{tabular}

For the samples that have been milled to a powder, maximum temperatures $\left(T_{\max }\right)$ were reached very rapidly after hydrogen peroxide addition and during the first three minutes of the induced chemical reaction. These maximum temperatures $\left(T_{\max }\right)$ are evidently present for all sulphide minerals and occur as distinct temperature peaks on the temperature-time curves ((Figures 3a and 4a, Supplementary Figures S4a-S7a). Measured temperatures never exceeded $90{ }^{\circ} \mathrm{C}$ (Figures $3 \mathrm{a}$ and $4 \mathrm{a}$, Supplementary Figures S4a-S7a). After reaching the maximum temperature, a progressive temperature decrease was observed in all powdered samples, which was discontinuous and much slower than the earlier temperature increase. This progressive temperature decrease was accompanied in some samples by another pronounced heat release lasting several minutes (Figure $4 a$, Supplementary Figures S4a and S7a) or an irregular slow temperature decrease over time (Figure 3a, Supplementary Figures S5a and S7a). The former pronounced heat release may relate to long-lasting exothermic reactions within the treated materials. Regardless, initial temperatures $\left(T_{\text {start }}\right)$ of all powdered samples were reached again after a reaction time of $60 \mathrm{~min}$, except for the galena sample (Figure 4a), which reached the initial temperature a bit later after $75 \mathrm{~min}$. Overall, all powdered sulphide samples display similar temperature-time progression curves.

Despite the similar temperature-time progression curves, there are considerable differences in the surface area beneath the temperature curves (Table 5). The surface area beneath the temperature-time progression curves reflects the relative temperature change over the time interval $(\mathrm{K} \cdot \mathrm{s})$ and consequently the reactivity of the sample during a single test run under the same experimental conditions. The integrals were calculated only for closed temperature-time progression curves of powdered materials (Table 5), based on the temperature differences compared to the initial temperature. Integrals of other coarse-grained sulphide mineral fractions could not be determined because their tests had to be stopped after $90 \mathrm{~min}$, which led to open temperature-time progression curves. For the integral calculation the temperatures were converted from ${ }^{\circ} \mathrm{C}$ to $\mathrm{K}$ and the time was converted from minutes [min] to seconds [s]. Comparing all powdered sulphide minerals, chalcopyrite $\left(228 \times 10^{2} \mathrm{~K} \cdot \mathrm{s}\right)$ shows the smallest surface area, followed by arsenopyrite $\left(231 \times 10^{2} \mathrm{~K} \cdot \mathrm{s}\right)$ and pyrite $\left(258 \times 10^{2} \mathrm{~K} \cdot \mathrm{s}\right)$. 
Other sulphides like iron-bearing sphalerite $\left(272 \times 10^{2} \mathrm{~K} \cdot \mathrm{s}\right)$, stibnite $\left(314 \times 10^{2} \mathrm{~K} \cdot \mathrm{s}\right)$ and non-iron bearing galena $\left(349 \cdot 10^{2} \mathrm{~K} \cdot \mathrm{s}\right)$ have comparatively higher integral values (Table 5).

Table 5. Integrals beneath temperature-time progression curves for the various powdered sulphide minerals. Integrals were only calculated for closed temperature-time progression curves. For the integral calculation the temperatures were converted from ${ }^{\circ} \mathrm{C}$ to $\mathrm{K}$ and the time was converted from minutes [min] to seconds [s].

\begin{tabular}{ccc}
\hline Mineral & Fraction Size & Integral $\int \mathbf{( K \cdot \mathbf { s } )}$ \\
\hline Pyrite & powdered & $258 \times 10^{2}$ \\
Chalcopyrite & powdered & $228 \times 10^{2}$ \\
Arsenopyrite & powdered & $231 \times 10^{2}$ \\
Stibnite & powdered & $314 \times 10^{2}$ \\
Galena & powdered & $349 \times 10^{2}$ \\
Sphalerite & powdered & $272 \times 10^{2}$ \\
\hline
\end{tabular}

The behaviour of powdered pyrite, when oxidised twice with $50 \mathrm{~mL}$ of $12 \% \mathrm{H}_{2} \mathrm{O}_{2}$, is shown in Figure 5. During the first addition of hydrogen peroxide, the temperature progression curve of powdered pyrite rapidly reached a maximum temperature of $90{ }^{\circ} \mathrm{C}$ and decreased to the initial temperature within $30 \mathrm{~min}$. Upon repeated addition of $50 \mathrm{~mL} 12 \% \mathrm{H}_{2} \mathrm{O}_{2}$, the material reached again a maximum temperature of $90^{\circ} \mathrm{C}$ (Figure 5), but the total duration of the second oxidation phase (75 min) was more than twice as long as that of the first oxidation phase (30 min). Thus, a single addition of $50 \mathrm{~mL} 12 \% \mathrm{H}_{2} \mathrm{O}_{2}$ did not completely dissolve the sulphide sample mass of $5 \mathrm{~g}$ and the reaction stopped due to the complete consumption and decay of $\mathrm{H}_{2} \mathrm{O}_{2}$.

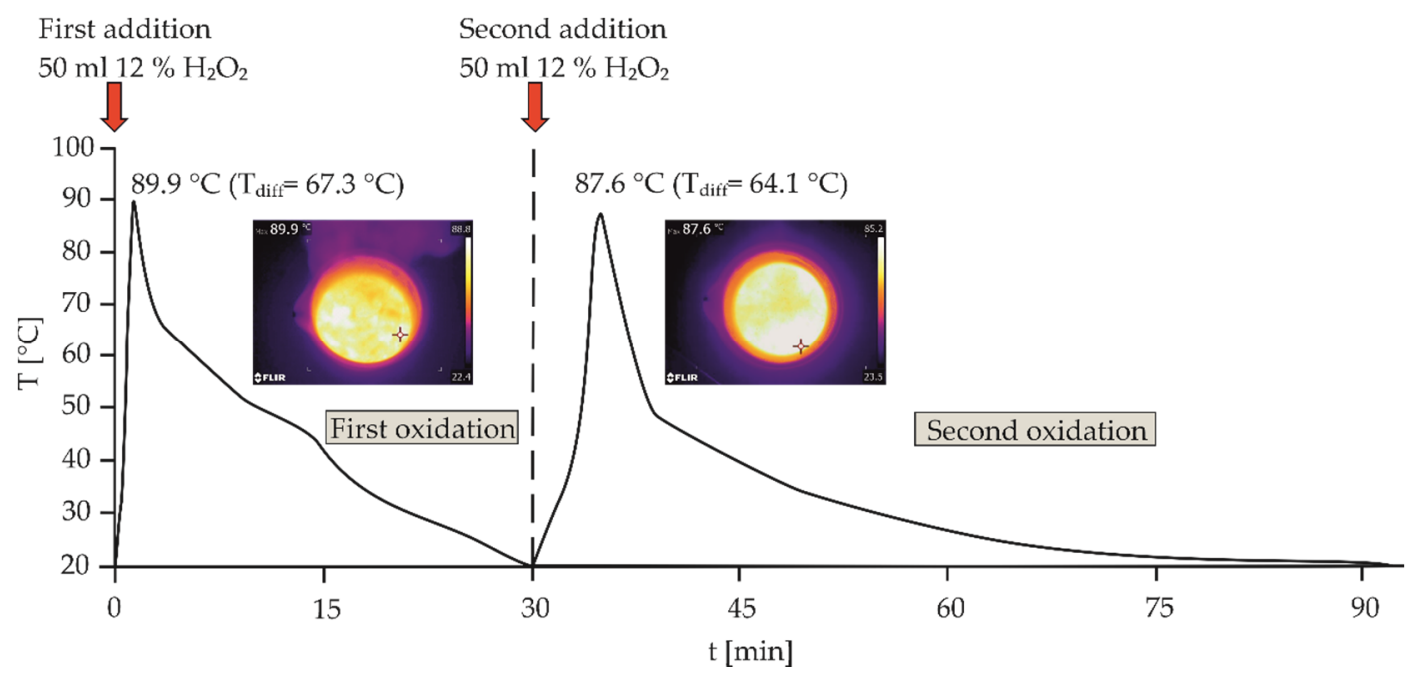

Figure 5. Two-stage oxidation of pyrite during IR thermography testing. The second exothermic event reaches the same maximum temperature of the first oxidation event again, but the cooling down phase takes more time to complete. Complete consumption and decay of hydrogen peroxide during the first oxidation event allowed additional pyrite oxidation.

The temperature-time progression curves of coarser milled and sieved mineral samples are unlike those of powdered materials (Figures 3a and 4a; Supplementary Figures S4a-S7a). Hydrogen peroxide treatment of the pyrite and chalcopyrite size fractions resulted in pronounced heat releases evident as distinct peaks (Figure 3b,c; Supplementary Figure S4b,c). Yet, compared to the powdered samples, the maximum temperatures $\left(T_{\max }\right)$ were reached much later in the two size fractions (Figure 3b,c; Supplementary Figure S4b,c). By contrast, hydrogen peroxide treatment of the galena, arsenopyrite, stibnite and sphalerite size fractions did not result in clearly recognisable temperature 
peaks over time (Figure $4 b, c$, Supplementary Figures S5b,c-S7b,c). Here, slightly increased temperature plateaus were reached after some reaction time (Figure 4b,c, Supplementary Figures S5b,c-S7b,c).

Overall, the temperature-time graphs demonstrate that the time taken to reach the maximum temperatures increases with increasing grain size. The intensity of the exothermic reaction between sulphides and hydrogen peroxide is greatest and readily recognisable using an IR camera, when the sample materials are powdered (Figures 3a and 4a; Supplementary Figures S4a-S7a).

Thus, hydrogen peroxide treatment of nearly monomineralic sulphide samples leads to distinct temperature peaks that can be visualised using an IR camera. Subsequently, in order to improve understandings of the behaviour of polymineralic materials, samples of variable pyrite:calcite mixtures were treated with hydrogen peroxide and temperature profile curves recorded (Figure 6). The temperature-time graphs show a progressive shift in the maximum temperature $\left(T_{\max }\right)$ with time as the proportion of pyrite decreases and that of calcite increases. The highest temperature difference ( $\left.T_{\text {diff }}\right)$ and the shortest time taken for the sample to react coincides with the sample with the highest pyrite content, and the temperature difference $\left(T_{\text {diff }}\right)$ progressively decreases and the time taken for the sample to react progressively increases with decreasing pyrite content. Yet, exothermic reactions of pyrite are still detectable by the IR method in samples that are dominated by the acid-consuming mineral calcite ( $98 \mathrm{wt} \%$ calcite). However, no temperature increase compared to the initial temperature could be recorded for calcite contents of more than $98 \mathrm{wt} \%$ and pyrite contents of less than $2 \mathrm{wt} \%$, on the contrary, the measured temperatures decreased compared to the initial temperatures $\left(T_{\text {start }}\right)$. The temperature differences for pyrite-calcite-mixtures with a pyrite concentration of $1 \mathrm{wt} \%, 0.5 \mathrm{wt} \%$ and $0.1 \mathrm{wt} \%$ are negative $\left(-0.7^{\circ} \mathrm{C},-0.7^{\circ} \mathrm{C}\right.$ and $-1.3^{\circ} \mathrm{C}$, respectively). In contrast, the results for the mixture of pyrite and quartz, treated with $\mathrm{H}_{2} \mathrm{O}_{2}$ showed, that a temperature difference of $T_{\text {diff }}=0.7^{\circ} \mathrm{C}$ could be still detected in samples with a pyrite concentration of $0.2 \mathrm{wt} \%$ and $99.80 \mathrm{wt} \%$ quartz $(0.2: 99.80$ pyrite:quartz). Pyrite:quartz ratios of 0.1:99.9 led to negative temperature differences $\left(T_{\text {diff }}<-1.5^{\circ} \mathrm{C}\right)$. The raw IR-data is provided in Supplementary Table S4.

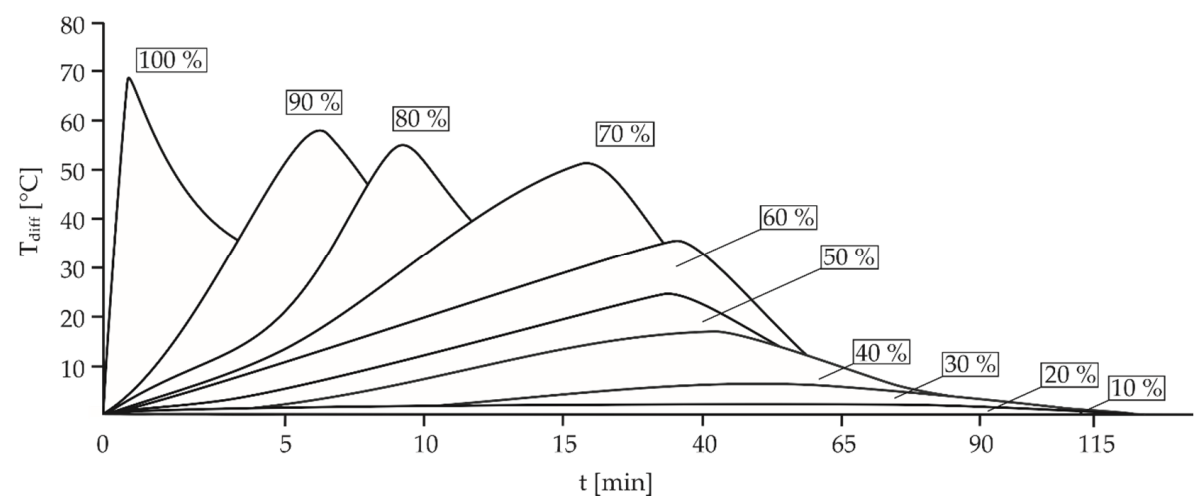

Figure 6. Heat release over time for the various pyrite-calcite mixtures (90:10 to 10:90 pyrite:calcite) during IR thermography testing. Decreasing pyrite concentrations result in lower maximum temperatures and a longer reaction time.

\section{Discussion}

Infrared thermography is commonly used to record and visualise heat in numerous industrial, behavioural and social settings. Thermographic methods and cameras are already used at mine sites to monitor the performance of machines, blasting operations [36], material flows [37] or in mine rescue situations [38]. Moreover, coal mines use thermographic methods to locate and detect areas of elevated temperatures, gas leaks and surface or subsurface fires in mines and heaps due to the oxidation of pyrite and marcasite [39-44]. Thermal imaging has also been used at active and abandoned mine sites to recognise mined from unmined areas [45], to locate fires [46], to grade crushed iron ores [47] and to study the environmental impact of heaps on soils and vegetation due to pyrite oxidation and associated heat release $[48,49]$. 
These aforementioned studies have predominantly documented the thermal imaging of naturally occurring sulphide oxidation and the associated heat release due to weathering. By contrast, the application of infrared thermographic cameras to recognise the likely presence of sulphide minerals in drill core, cutting, chips and powders has not been investigated. Such a procedure has the potential to predict the likely presence of sulphide minerals in sampled materials at the exploration stage of mining. In this study, sulphidic ore samples were specifically and intentionally oxidised, following a defined test protocol, to record and to visualise any exothermic reactions and associated heat release from sulphidic minerals. In general, thermal imaging tests can only be carried out when sunlight is absent or at night [45,49], because solar radiation and other daylight reflections falsify the measured temperature differences between oxidising sulphide minerals and the non-sulphidic surroundings. This factor did not pose a limitation in the present study, because samples were shielded from outside solar radiation and thermal reflections.

Pyrite oxidation is an exothermic reaction, and its degradation can be described in a series of steps, which were originally described by Garrels and Thompson [50] and Singer and Stumm [51]. In listed equations below, the standard enthalpy of reaction $\left(\Delta \mathrm{H}_{\mathrm{r}}{ }^{0}\right)$ is indicated too, as described by the CRC Handbook of Chemistry and Physics [52].

$$
\begin{gathered}
\mathrm{FeS}_{2}+\frac{7}{2} \mathrm{O}_{2}+\mathrm{H}_{2} \mathrm{O} \rightarrow \mathrm{Fe}^{2+}+2 \mathrm{SO}_{4}^{2-}+2 \mathrm{H}^{+} \Delta \mathrm{Hr} 0=-1443 \mathrm{~kJ} / \mathrm{mol} \\
\mathrm{Fe}^{2+}+\frac{1}{4} \mathrm{O}_{2}+\mathrm{H}^{+} \rightarrow \mathrm{Fe}^{3+}+\frac{1}{2} \mathrm{H}_{2} \mathrm{O} \Delta \mathrm{H}_{\mathrm{r}}{ }^{0}=-102 \mathrm{~kJ} / \mathrm{mol} \\
\mathrm{FeS}_{2}+14 \mathrm{Fe}^{3+}+8 \mathrm{H}_{2} \mathrm{O} \rightarrow 15 \mathrm{Fe}^{2+}+2 \mathrm{SO}_{4}^{2-}+16 \mathrm{H}^{+} \Delta \mathrm{H}_{\mathrm{r}}^{0}=-16 \mathrm{~kJ} / \mathrm{mol}
\end{gathered}
$$

In general, enthalpy $(\mathrm{H})$ is a thermodynamic function, which describes the sum of all internal energies in a system, which is especially useful for thermodynamic reactions with constant pressure (p) [52]. The applied IR test as also conducted under constant pressure conditions. Exothermic reactions, like the oxidation of sulphides, are accompanied by enthalpy changes $(\Delta \mathrm{H})$, due to the transfer of thermal energy, which results in a negative standard enthalpy of reaction $\left(\Delta \mathrm{H}_{\mathrm{r}}{ }^{0}<0\right)$. The aqueous oxidation of pyrite is a strongly exothermic reaction (Equations (2)-(4)), mainly due to the oxidation of intermediate $\mathrm{S}_{2}$ through $\mathrm{O}_{2}[53,54]$, which results in a heat release of $1443 \mathrm{~kJ}$ for one oxidised mole of pyrite. The fact that the oxidation of sulphides is an exothermic reaction has also been proven and discussed in detail by numerous thermal analysis and calorimetric studies [55-65]. In the present study, hydrogen peroxide was used as a strong oxidant to speed up sulphide oxidation reactions [66]. Due to the lack of toxic by-products [67], hydrogen peroxide is suited for the described experimental set-up, although precious and transition metals (e.g., $\mathrm{Ag}, \mathrm{Cu}, \mathrm{Fe}, \mathrm{Mn}, \mathrm{Ni}$ and $\mathrm{Pt}$ ) as well as their oxides accelerate the decomposition of hydrogen peroxide [19,68-72]. Consequently, all of the hydrogen peroxide added to a particular sample is not available for the oxidation of sulphides if such metals or their oxide compounds are present. In addition, the $\mathrm{H}_{2} \mathrm{O}_{2}$ treatment also accelerates the sulphide oxidation reaction and causes an alteration of the sulphide minerals surface, including the formation of coatings [73]. The effect of coat formation (microencapsulation) has been used and described in detail by Evangelou [73] to protect pyrite in coal waste against further oxidation using a mixture of $\mathrm{H}_{2} \mathrm{O}_{2}$ and $\mathrm{K}_{2} \mathrm{HPO}_{4}$, which lead to the participation of ferric phosphate layers on the surface of pyrite [73]. Furthermore, the oxidation of sulphides through $\mathrm{H}_{2} \mathrm{O}_{2}$ only reflects the chemical oxidation and does not consider biological oxidation reaction rates, which occur in nature. Apart from this, the application of $\mathrm{H}_{2} \mathrm{O}_{2}$ does not take into account any climatic conditions. The importance of the last two points mentioned, and the resulting effects on sulphide oxidation rates, was discussed at length by Elberling [74,75].

Nevertheless, hydrogen peroxide has been a common and frequently used oxidising agent for several decades and has been used in numerous environmental studies, especially in NAG tests 
and variations thereof. The oxidation of pyrite through hydrogen peroxide can be described by the following exothermic reactions, which also lists the standard enthalpy of reaction $\left(\Delta \mathrm{H}_{\mathrm{r}}{ }^{0}\right)$ [76-78]:

$$
\begin{gathered}
\mathrm{FeS}_{2}+\frac{15}{2} \mathrm{H}_{2} \mathrm{O}_{2} \rightarrow \mathrm{Fe}^{3+}+2 \mathrm{SO}_{4}^{2-}+\mathrm{H}^{+}+7 \mathrm{H}_{2} \mathrm{O} \Delta \mathrm{H}_{\mathrm{r}}{ }^{0}=-2288.9 \mathrm{~kJ} / \mathrm{mol} \\
\mathrm{FeS}_{2}+14 \mathrm{Fe}^{3+}+8 \mathrm{H}_{2} \mathrm{O} \rightarrow 15 \mathrm{Fe}^{2+}+2 \mathrm{SO}_{4}^{2-}+16 \mathrm{H}^{+} \Delta \mathrm{H}_{\mathrm{r}}{ }^{0}=-1.3 \mathrm{~kJ} / \mathrm{mol}
\end{gathered}
$$

Results from a previous study [79] showed that $\mathrm{H}_{2} \mathrm{O}$ is still an important oxidant in pyrite oxidation if $\mathrm{H}_{2} \mathrm{O}_{2}$ is present and if $\mathrm{Fe}^{2+}$ occurred in the solution, indicating a reducing reverse reaction from $\mathrm{Fe}^{3+}$ to $\mathrm{Fe}^{2+}$ [79]. This reducing back reaction is also demonstrated by the NAGpH test results in the present study (Figure 1), as the oxidation of pyrite through $\mathrm{H}_{2} \mathrm{O}_{2}(\mathrm{NAGpH}=2.27$, Eh = 539) plots in the stability field of $\mathrm{Fe}^{2+}$ in the Eh-pH diagram for the $\mathrm{FeS}_{2}-\mathrm{H}_{2} \mathrm{O}$ system at $25^{\circ} \mathrm{C}$ temperature. Because of this, the last two reactions of pyrite oxidation through $\mathrm{H}_{2} \mathrm{O}_{2}$ and $\mathrm{H}_{2} \mathrm{O}$ (Equations (5) and (6)) can be summarised [79]:

$$
\mathrm{FeS}_{2}+10 \mathrm{Fe}^{3+}+4 \mathrm{H}_{2} \mathrm{O}+2 \mathrm{H}_{2} \mathrm{O}_{2} \rightarrow 11 \mathrm{Fe}^{2+}+2 \mathrm{SO}_{4}^{2-}+12 \mathrm{H}^{+} \Delta \mathrm{H}_{\mathrm{r}}{ }^{0}=-608.3 \mathrm{~kJ} / \mathrm{mol}
$$

Thus, hydrogen peroxide is a strong oxidant to oxidise sulphide minerals accompanied by a release of thermal energy (heat). This heat can then be recorded and measured by a thermal imaging camera against time and heat release intensity. This is illustrated by comparing the temperature-time progression curves obtained using the thermal imaging camera and the digital thermometer (Figures 3a and 4a; Supplementary Figures S4a-S7a, Supplementary Table S3). The progression of the temperature-time curves of powdered materials from both temperature measuring methods show the same trends. Only in the case of stibnite (Supplementary Figure S6), there is a larger temperature mismatch between minute 3 up to 8 , as the second phase of heat release is not as pronounced when measuring with the digital thermometer, which was also found for chalcopyrite and galena but of less significance. Other small deviations can be explained by the fact that the use of a digital thermometer represents a selective measurement of a point with a measurement sensor. The thermal imaging camera, however, shows based on the settings the hot spot temperature of a selected image section or the temperature of the whole sample surface. Furthermore, the digital thermometer detects the temperatures inside the liquid, whereas the thermal imaging camera records the temperatures contactless on the surface.

Results of this study documented in the pilot study (Figure 2, Supplementary Figures S1-S3) and the temperature-time progression curves (Figures 3a and 4a, Supplementary Figures S4a-S7a) demonstrate that the application of hydrogen peroxide to fine-grained sulphide minerals leads to intense exothermic oxidation reactions, independent of the type of sulphide mineral present. Yet, the various tested sulphides display subtle differences in the maximum temperature reached $\left(T_{\max }\right)$, the reaction time to reach the peak temperature $\left(t_{\max }\right)$, and the total time $\left(t_{\text {total }}\right)$ to reach the initial temperature ( $\left.T_{\text {start }}\right)$. Miller et al. [30,31] described the maximum temperature during the NAG test of pyrite as a function of the sulphur content and reactivity and classified sulphides as "highly reactive" if the maximum temperature peak $\left(T_{\max }\right)$ was reached within the first five minutes of the reaction. However, other sulphide minerals, absolute temperature differences and the total duration of the reaction were not considered. Based on the described recorded parameters above (Table 1), conclusions can be drawn about the reactivity of the individual sulphide minerals used in this study.

Results from the IR method show that poorly reactive samples like the $2-4 \mathrm{~mm}$ size fractions of chalcopyrite, arsenopyrite, sphalerite, galena and stibnite are characterised by a temperature difference of less than $10^{\circ} \mathrm{C}$ (Table 4). The effect of the grain size on the sulphide oxidation rate was sufficiently investigated by Dold and Fontboté [80] using pyrite and chalcopyrite bearing tailings. The results here indicate that powdered pyrite reached its maximum temperature of $90^{\circ} \mathrm{C}$ the fastest and cooled down to the initial temperature $\left(T_{\text {start }}\right)$ the fastest as well. In addition, significant high temperature releases could be recorded in the two size fractions of pyrite and chalcopyrite (Figure 3), which is not the case 
for the other investigated sulphide minerals. By contrast, galena took the longest time to reach its initial temperature $\left(T_{\text {start }}\right)$ again, and it had the lowest maximum temperature of $67.8^{\circ} \mathrm{C}\left(T_{\max }\right)$ (Figure 4$)$, which is below the maximum temperatures of all other tested sulphides. The two galena coarse grain size fractions also form a temperature plateau (Figure $4 b, c$ ), where the maximum temperatures are nearly constant for approximately $90 \mathrm{~min}\left(32.6{ }^{\circ} \mathrm{C}\right.$ and $30.5{ }^{\circ} \mathrm{C}$, respectively). This likely reflects a constant energy release from enduring exothermic galena oxidation reactions and the continuing consumption of hydrogen peroxide. Compared to iron sulphides (e.g., pyrite, chalcopyrite and arsenopyrite), galena needs a significantly higher activation energy for oxidation due to the fully loaded orbitals of lead and sulphur, making the transfer of the spin density from $\mathrm{O}_{2}$ to lead and sulphur comparatively harder [81]. Furthermore, the transfer of Fe(II) in pyrite is predominantly to the oxidant, while the electrons in galena are withdrawn from sulphur ions during the reaction of oxidation [81]. Such crystallographic controls may explain the detected sustained energy release upon galena oxidation as detected through IR thermography by this study.

Differences in the reactivities of the individual sulphide sample materials are also indicated by the calculated areas under the temperature-time graphs (Table 5). Having applied the same experimental set-up and conditions, comparatively small surface areas indicate a higher reactivity of the sulphide material caused by a faster consumption and decay of hydrogen peroxide, which resulted in a faster cooling down and an end of the oxidation reactions. By contrast, lower reactive samples led to slower oxidation, the consequence being that the consumption and the decay of hydrogen peroxide was decelerated as well. Thus, a prolonged heat release can take place, provided there is enough sulphide material which can be oxidised. Calculation of the areas beneath the temperature-time progression curves confirms that chalcopyrite followed by arsenopyrite and pyrite have the smallest calculated areas $\left(229 \times 10^{2} \mathrm{~K} \cdot \mathrm{s} ; 234 \times 10^{2} \mathrm{~K} \cdot \mathrm{s}\right.$ and $241 \times 10^{2} \mathrm{~K} \cdot \mathrm{s}$, respectively), and therefore these three sulphide minerals are the most reactive minerals investigated by this study. By comparison, galena displays the largest calculated area of $354 \times 10^{2} \mathrm{~K} \cdot \mathrm{s}$ (Table 5), and it is therefore the least reactive sulphide mineral analysed by this study. This leads to the following order of sulphide reactivity of powdered sample material from high to low: chalcopyrite $>$ arsenopyrite $>$ pyrite $>$ sphalerite $>$ stibnite $>$ galena. Fe has been showed to have a decisive influence on the reactivity of sulphides [82]. This is evident in the reactivity of sphalerite, which has a higher Fe concentration (7.62 wt \%, Table 3) compared to stibnite with only slightly increased Fe content $(0.05 \mathrm{wt} \%$, Table 3$)$, and galena, for which no Fe above the LOD has been detected (Table 3). Chopard et al. [83] determined in their study the reactivity of monomineralic sulphides almost in the same order but using kinetic tests with a test time of 200 days. The only difference is the reactivity of chalcopyrite, which shows a higher reactivity in the present study, caused by the high purity of the sample material of $100 \mathrm{wt} \%$ chalcopyrite (Table 2). Therefore, the highest possible amount of Fe is available for chalcopyrite oxidation (Table 3). The rate of chalcopyrite oxidation increase with increasing Fe concentrations [82]. In contrast, the sample material of pyrite and arsenopyrite show impurities (15 wt\% and $31 \mathrm{wt} \%$ respectively, Table 2), which led to a reduced reactivity. The oxidation rates of pyrite and arsenopyrite are equivalent if ferric Fe is the oxidant $[84,85]$. The results of the integral calculations show that the reactivity of the sulphides can be successfully and rapid determined within one to two hours using the described IR test protocol. The integral results also demonstrate that the IR test reacts to changes in sulphide sample reactivity. Fe impurities lead to an increased sulphide reactivity. Reduced sample reactivity can be due to non-sulphide minerals in the sample material. The IR results underline the importance of knowing the trace element composition in the sample material for sulphide reactivity classification [85].

Some powdered sulphides, especially chalcopyrite, stibnite and galena, show a second phase of heat release after the maximum temperature $\left(T_{\max }\right)$ was reached (Figure 4; Supplementary Figures $S 4$ and S6). This second temperature rise could be interpreted as a second exothermic event, which occurred due to cracking of freshly formed protective secondary mineral coatings around the sulphide particles. Upon exothermic sulphide oxidation events, mineral coatings (e.g., oxides, sulphates) may form as outer layers especially on fine-grained sulphide particles, encapsulating and protecting the sulphide 
grains from further oxidation (cf. Dunn 1997). Thus, the second energy release as detected by this study in powdered sulphide minerals is most likely due to the initial formation and subsequent dissolution of oxidation products on sulphide mineral surfaces.

Overall, a maximum temperature $\left(T_{\max }\right)$ of more than $90{ }^{\circ} \mathrm{C}$ was never exceeded in any of investigated materials, which is consistent with the observations of Miller et al. [29,30], Weber et al. [19,33] and Sapsford et al. [32] in previous studies. This could be due the boiling point of $12 \% \mathrm{H}_{2} \mathrm{O}_{2}$, which is around $100{ }^{\circ} \mathrm{C}$ at sea level [86], the energy loss to the surroundings because of vapour formation and the use of a non-insulated beaker. Another factor influencing the intensity and duration of the exothermic reaction is the amount of sulphide material present (Figure 6). The lower the pyrite content, the more time was needed to reach the maximum temperature, which was also accompanied by a change in the shape of the temperature peaks, becoming increasingly round and broad (Figure 6). In addition, the duration of the exothermic reaction increased with decreasing pyrite contents. This demonstrates that a decreasing pyrite content resulted in a decreasing intensity of the exothermic reaction. The energy output is slower, but the exothermic reaction takes place over a longer period (Figure 6). By contrast, high pyrite concentrations led to more rapid and explosive reactions, accompanied by rapid heat emissions with vapour formation. Furthermore, self-heating of sulphide-rich material is greater when compared to samples with lower sulphide concentrations due to the spontaneous reaction with oxygen after desulfurisation as documented in a kinetic study by Wang et al. [57]. The oxidation of sulphides is a temperature-dependent reaction $[73,75]$ and heat is a catalyst for further exothermic reactions, with the result being that oxidation proceeds faster at higher than lower temperatures $[67,87,88]$. Consequences of rapid decay and consumption of hydrogen peroxide [89] are comparatively faster cooling to the initial temperature ( $\left.T_{\text {start }}\right)$. Comparably lower pyrite concentrations led to exothermic reactions of lower intensities with slower consumption and decay of hydrogen peroxide. As a result, hydrogen peroxide is available longer for exothermic reactions, which led to longer reaction times $\left(t_{\text {total }}\right)$ overall. However, for a pyrite concentration of $1 \mathrm{wt} \%$ or lower, a temperature decrease relative to the initial temperature was recorded if it was mixed with calcite, resulting in negative temperature differences $\left(T_{\text {diff }}<0{ }^{\circ} \mathrm{C}\right)$. However, if pyrite was mixed with quartz it led to the observation that significant temperature increases could be still detected down to a pyrite concentration of $0.2 \mathrm{wt} \%$. Only from a pyrite content of $0.1 \mathrm{wt} \%$ or lower, mixed with quartz were negative temperature differences measured. The reason for negative temperature differences is that, the heat released by the exothermic reaction is so small that it can no longer be detected due to the loss of energy. Furthermore, the sample cools due to cooling by evaporation. Moreover, the amount of energy that is extracted from the liquid is greater than the energy (heat) released by the exothermic reaction and the temperature differences $\left(T_{\text {diff }}\right)$ become negative. The lower the pyrite:calcite $(\leq 1: 99)$ and pyrite:quartz ratio $(\leq 0.1: 99.90)$, the greater the negative temperature differences. However, the addition of calcite seems to increase the effect of the negative temperature differences. One factor is the activation energy of pyrite. Calcite is an acid-consuming mineral, known for its fast acid-neutralisation reactions and therefore commonly used for AMD treatment. The activation energy of pyrite is low at low $\mathrm{pH}$ and increases with increasing $\mathrm{pH}$ [90]. Therefore, the oxidation of pyrite takes place faster under lower $\mathrm{pH}$ values than under higher $\mathrm{pH}$. Due to the mixture of pyrite and calcite the $\mathrm{pH}$ is raised and a higher activation energy is necessary to oxidise pyrite. In addition, sulphide-rich samples consume calcite faster than samples poor in sulphides [90]. The barrier that must be exceeded for pyrite oxidation increases with decreasing pyrite:calcite ratio. Yet, an opposite effect was reported by Evangelou and Zhang [91], who described increased pyrite oxidation rates caused by $\mathrm{HCO}_{3}{ }^{-}$, the main chemical compound at $\mathrm{pH} 7$ [85] due to buffering by carbonate minerals. Besides the neutralising treatment of acidic waters, this can also lead to an increased kinetic pyrite oxidation behaviour [85]. Increased pyrite oxidation rate due to the addition of calcite could not be detected in this study.

Based on these results, a general detection limit for pyrite cannot be set for the developed infrared thermographic test protocol, as the detection limit varies depending on the influencing factors and parameters. One factor is the sulphide mineral phase itself, because the standard enthalpy of 
reaction, the oxidation reactivity behaviour and the associated energy transfer in form of heat varies from sulphide to sulphide and depends on particle size (Figures 3a and 4a, Supplementary Figures S4a-S7a), which has already been documented and discussed in studies using calorimetric methods [55,60,92] and scanning tunnelling microscopy [81]. Furthermore, no mineral-specific general detection limits can be defined, because partially oxidised pyrite has a greater heat evolution compared to fresh non-oxidised pyrite due to the catalysing effect of precipitated iron sulphates on the pyrite surface [63]. This effect can also be expected for other iron-bearing sulphides. Consequently, detection limits can only be defined if the experimental set-up and the controlling parameters are specified. Accordingly, the detection limit for powdered, pure and non-oxidised pyrite mixed with pure powdered calcite, using the described infrared thermographic test protocol in the present study is defined as $2 \mathrm{wt} \%$. Pyrite concentrations below $2 \mathrm{wt} \%$ lead to negative temperature differences if it is mixed with calcite. In contrast, the detection limit for powdered, pure and non-oxidised pyrite mixed with pure powdered quartz, using the described infrared thermographic test protocol is $0.2 \mathrm{wt} \%$. Pyrite concentrations below $0.2 \mathrm{wt} \%$ lead to negative temperature differences if pyrite is mixed with quartz.

Furthermore, it is evident in the present study that the detected temperature-time profiles are dependent on the availability of hydrogen peroxide. Repeated addition of $12 \% \mathrm{H}_{2} \mathrm{O}_{2}$ led to renewed exothermic pyrite oxidation with nearly similar maximum temperatures $\left(T_{\max }\right)$ (Figure 5). Consequently, the oxidation reaction of highly reactive sulphidic samples stops due to the complete consumption and decay of hydrogen peroxide and not due to the complete oxidation of the sulphide sample material, which was described in various NAG test studies before (c.f. [18,30,83-86,93]). Clear maximum temperature peaks are indicators of full decomposition of $\mathrm{H}_{2} \mathrm{O}_{2}$ and consequently named by Weber et al. as the "catalytic decomposition peak of $\mathrm{H}_{2} \mathrm{O}_{2}$ " [94].

Finally, based on the test results and observations, an error analysis can be carried out for the infrared thermographic test protocol developed here. All tests were performed with a non-insulated beaker; consequently, there is an unmeasured loss of heat to the surroundings. In addition, with highly reactive samples, energy is also lost due to the formation of vapour in the course of the phase transition from liquid phase to vapour. Furthermore, not the entire hydrogen peroxide is available to react with the sulphides, as Fe and its oxides in particular, but also other metals (e.g., Ag, Cu, Mn, Ni, Pt), may act catalytically on hydrogen peroxide. Therefore, a certain amount of hydrogen peroxide possibly decomposes before it may react with sulphides. All the above mentioned energy losses and the loss of reactive hydrogen peroxide can lead to low abundances of sulphides being undetectable in samples using a thermographic camera.

pXRF is a common and recommended method for identifying sulphide minerals in the field using geochemical data. The advantage of the described IR test protocol in this study compared to pXRF is that no specialist personnel are required to perform the tests. In addition, mining companies already use IR cameras on site for safety monitoring and other applications as described above. Therefore, IR cameras are a well-known technique for mine personnel and existing technical infrastructure can be used. Furthermore, in recent years IR cameras have become cheaper, more compact, easy to handle and easy to purchase. There is no need for additional security training or security personnel as is the case when using X-ray equipment. The IR cameras are easy to transport, robust and have rechargeable and exchangeable batteries, making the IR cameras easy to use in the field. In addition, IR cameras are quickly ready for operation after an usually warm-up phase of five to ten minutes and calibrate themselves within one minute each time they are restarted. There is no need for time-consuming calibrations, system checks and the acquisition of expensive certified reference materials, because it is a standalone system. In short distances, as applied in the present study, differences in air pressure and humidity have no influence on the IR measurements. Both methods, IR and pXRF, complement each other to enable sample classification in the field.

Further and future investigations with other non-sulphide minerals mixed with sulphides are necessary to have a better understanding of the thermodynamic reaction behaviour of sulphides when they are mixed with other non-sulphide minerals and treated with $\mathrm{H}_{2} \mathrm{O}_{2}$. Also, further tests 
are necessary to find out if and how different sulphide mineral phases influence each other during oxidation by $\mathrm{H}_{2} \mathrm{O}_{2}$ due to electrochemical processes [95]. Tests on real (natural) deposits are planned as part of future work.

\section{Conclusions}

This study demonstrates that the presence and reactivity of exothermic sulphide oxidation reactions can be measured and visualised using a portable IR thermographic camera when powdered sulphidic materials were treated with hydrogen peroxide. The reactivity of powdered sulphide minerals analysed in this study from high to low is chalcopyrite $>$ arsenopyrite $>$ pyrite $>$ sphalerite $>$ stibnite $>$ galena. The duration and intensity of the visualised reactions depend on (i) the inherent reactivity of the respective sulphide minerals, (ii) the amount of sulphides present, (iii) the available reactive surface, (iv) the degree of previous oxidation/weathering, (v) the volume and concentration of the hydrogen peroxide added, (vi) potential iron impurities and (vii) the presence of other mineral phases. Despite the presence of calcite, sulphide minerals can be visualised down to the mineral-specific detection limit using IR thermography due to exothermic sulphide oxidation reactions. This study also demonstrates that the application of hydrogen peroxide to powdered sulphidic samples and subsequent IR thermography allow rapid recognition and visualisation of sulphide minerals and the associated sample reactivity within samples regardless of the presence of calcite and regardless of $\mathrm{pH}$.

Supplementary Materials: The following are available online at http://www.mdpi.com/2075-163X/10/11/933/s1, Table S1: Raw pXRF data, LOD's, precision and accuracy; Table S2: Raw IR-data; Table S3: Raw data using digital thermometer; Table S4: Raw IR-data pyrite:calcite and pyrite:quartz proportions; Figure S1: Pilot study sample heated; Figure S2: Pilot study using iron(III) chloride on surface; Figure S3: Pilot study roughened surface; Figure S4: Temperature-time graphs for chalcopyrite; Figure S5: Temperature-time graphs for arsenopyrite; Figure S6: Temperature-time graphs for stibnite; Figure S7: Temperature-time graphs for sphalerite.

Author Contributions: Conceptualization: M.K. and B.G.L.; methodology: M.K.; validation: M.K.; formal analysis: M.K.; investigation: M.K.; data curation: M.K.; writing-original draft preparation: M.K.; writing-review and editing: B.G.L.; funding acquisition: B.G.L. All authors have read and agreed to the published version of the manuscript.

Funding: Parts of this study were financially supported by the European Union's Horizon 2020 research and innovation programme under grant agreement No. 730411.

Acknowledgments: We thank N. Willing (RWTH Aachen) for help with the sample preparation and L.W. Palmer (University of Exeter) for language editing. Two anonymous referees are acknowledged for their constructive criticism of the manuscript.

Conflicts of Interest: The authors declare no conflict of interest.

\section{References}

1. Lottermoser, B.G. Preface. In Environmental Indicators in Metal Mining; Lottermoser, B.G., Ed.; Springer International Publishing: Berlin/Heidelberg, Germany, 2017; pp. v-viii, ISBN 978-3-319-42729-4.

2. Parbhakar-Fox, A.; Lottermoser, B.G. A critical review of acid rock drainage prediction methods and practices. Miner. Eng. 2015, 82, 107-124. [CrossRef]

3. Vink, B.W. Stability relations of antimony and arsenic compounds in the light of revised and extended Eh-pH diagrams. Chem. Geol. 1996, 130, 21-30. [CrossRef]

4. Ashley, P.M.; Craw, D.; Graham, B.P.; Chappell, D.A. Environmental mobility of antimony around mesothermal stibnite deposits, New South Wales, Australia and southern New Zealand. J. Geochem. Explor. 2003, 77, 1-14. [CrossRef]

5. Wilson, S.C.; Lockwood, P.V.; Ashley, P.M.; Tighe, M. The chemistry and behaviour of antimony in the soil environment with comparisons to arsenic: A critical review. Environ. Pollut. 2010, 158, 1169-1181. [CrossRef]

6. INAP. Prediction tools. In Global Acid Rock Drainage Guide (GARD). Available online: www.gardguide. com/index.php?title=Main_Page (accessed on 2 October 2020).

7. Hageman, P.L. U.S. Geological Survey Field Leach Test for Assessing Water Reactivity and Leaching Potential of Mine Wastes, Soils, and Other Geologic and Environmental Materials; Techniques and Methods; U.S. Department of the Interior, U.S. Geological Survey: Reston, VA, USA, 2007; ISBN 978-1-4113-1798-7. 
8. Ackerman, L.; Rohovec, J.; Šebek, O. Determination of total sulfur in fifteen geological materials using inductively coupled plasma-optical emission spectrometry (ICP-OES) and combustion/infrared spectrometry. Geostand. Geoanal. Res. 2012, 36, 407-414. [CrossRef]

9. Okai, T.; Terashima, S.; Imai, N. Determination of total sulfur in thirty one geochemical reference materials using an inductively coupled plasma-atomic emission spectrometer fitted with a semiconductor photodiode detector. Geostand. Geoanal. Res. 2001, 25, 133-136. [CrossRef]

10. Terashima, S. Determination of total carbon and sulfur in fifty-two geochemical reference samples by combustion and infrared absorption spectrometry. Geostand. Geoanal. Res. 1988, 12, 249-252. [CrossRef]

11. Jackson, L.L.; Roof, S.R. Determination of the forms of carbon in geologic materials. Geostand. Newslett. 1992, 16, 317-323. [CrossRef]

12. Paktunc, A.D. Mineralogical constraints on the determination of neutralising potential and prediction of acid mine drainage. Environ. Geol. 1999, 39, 103-112. [CrossRef]

13. Dold, B. Acid rock drainage prediction: A critical review. J. Geochem. Explor. 2017, 172, 120-132. [CrossRef]

14. Coastec Research Inc. A Manual of Chemical Evaluation Procedures for the Prediction of Acid Generation from Mine Wastes; Energy, Mines and Resources, Canada, MEND Report 1.16.1 (b); Coastec Research Inc.: Vancouver, BC, Canada, 1991; p. 77.

15. Lapakko, K.A. Evaluation of neutralization potential determinations for metal mine waste and a proposed alternative. Am. Soc. Min. Reclam. 1994, 129-137. [CrossRef]

16. Price, W.A.; Errington, J.C. Guidelines for metal leaching and acid rock drainage at minesites in British Columbia. In Proceedings of the Fourth International Conference on Acid Rock Drainage, Vancouver, BC, Canada, 31 May-6 June 1997; Volume 1, pp. 15-30.

17. Lawrence, R.W.; Wang, Y. Determination of neutralization potential in the prediction of acid rock drainage. In Proceedings of the Fourth International Conference on Acid Rock Drainage, Vancouver, BC, Canada, 31 May-6 June 1997; pp. 449-464.

18. Karlsson, T.; Räisänen, M.L.; Lehtonen, M.; Alakangas, L. Comparison of static and mineralogical ARD prediction methods in the Nordic environment. Environ. Monit. Assess. 2018, 190, 1-29. [CrossRef] [PubMed]

19. Weber, P.A.; Thomas, J.E.; Skinner, W.M.; Smart, R.S.C. Calculated acid base balance for H2O2 oxidation of carbonate-poor pyritic mine-rock. Canad. Mineral. 2005, 43, 1193-1203. [CrossRef]

20. Weber, P.A.; Thomas, J.E.; Skinner, W.M.; Smart, R.S.C. A methodology to determine the acid-neutralization capacity of rock samples. Canad. Mineral. 2005, 43, 1183-1192. [CrossRef]

21. Stewart, W.A.; Miller, S.D.; Smart, R. Advances in acid rock drainage (ARD) characterisation of mine wastes. In Proceedings of the 7th ICARD, St. Louis, MO, USA, 26-30 March 2006; pp. 2098-2119.

22. Deopker, R.D.; O'Connor, W.K. Column leach study 1: Heavy metal dissolution characteristics from selected copper mine tailings. Mine Water Environ. 1991, 10, 57-71. [CrossRef]

23. Noble, T.L.; Lottermoser, B.G.; Parbhakar-Fox, A. Evaluation of $\mathrm{pH}$ testing methods for sulfidic mine waste. Mine Water Environ. 2016, 35, 318-331. [CrossRef]

24. Oh, C.; Ji, S.; Yim, G.; Cheong, Y. Evaluation of net acid generation $\mathrm{pH}$ as a single indicator for acid forming potential of rocks using geochemical properties. Environ. Monit. Assess. 2017, 189, 165. [CrossRef]

25. Smart, R.; Skinner, W.M.; Gerson, A.R.; Thomas, J.E.; Sobieraj, H.; Schumann, R.; Weisener, C.G.; Weber, P.A.; Miller, S.D.; Stewart, W.A. ARD Test Handbook: Project P387, A Prediction E Kinetic Control of Acid Mine Drainage; AIMIRA International Ltd.: Melbourne, Australia, 2002.

26. Reimers, G.W.; Franke, D.F. Effect of Additives on Pyrite Oxidation; Report of investigations; United States Bureau of Mines: Washington, DC, USA, 1991; p. 13.

27. Banks, D.; Skarphagen, H.; Wiltshire, R.; Jessop, C. Heat pumps as a tool for energy recovery from mining wastes. In Energy, Waste and the Environment: A Geochemical Perspective; Gieré, R., Stille, P., Eds.; The Geological Society: London, UK, 2004; pp. 499-514.

28. Shamsuddin, M. Roasting of Sulfide Minerals. In Physical Chemistry of Metallurgical Processes; John Wiley \& Sons, Inc.: Hoboken, NJ, USA, 2016; pp. 39-69, ISBN 978-1-119-07832-6.

29. Miller, S.D.; Jeffery, J.J.; Donohue, T.A. Development in predicting and managament of acid forming mine watses in Australia and Southeast Asia. In Proceedings of the International Land Reclamation and Mine Drainage Conference and the Third International Conference on the Abatement of Acidic Drainage, Pittsburgh, PA, USA, 24-29 April 1994; pp. 177-184. 
30. Miller, S.D.; Jeffery, J.J.; Murray, G.S.C. Identification and management of acid generating mine wastes-procedures and practices in south-east Asia and the Pacific regions. Int. J. Mine Water 1990, 9, 57-67. [CrossRef]

31. Miller, S.D.; Jeffery, J.J.; Wong, J.W.C. Use and misuse of the acid-base account for AMD prediction. In Proceedings of the Conference on the Abattement of Acidic Drainage, Montreal, QC, Canada, 16-18 September 1991; pp. 489-506.

32. Sapsford, D.J.; Bowell, R.J.; Dey, M.; Williams, M.C.; Williams, K.P. A comparison of kinetic NAG tests with static and humidity cell tests for the prediction of ARD. In Proceedings of the 10th International Mine Water Association Congress, Karlovy Vary, Czech Republic, 2-5 June 2008; pp. 1-4.

33. Weber, P.A.; Hughes, J.B.; Conner, L.B.; Lindsay, P.; Smart, S.C.R. Short-term acid rock drainage characteristics determined by paste $\mathrm{pH}$ and kinetic NAG testing: Cypress prospect, New Zealand. In Proceedings of the 7th ICARD, St. Louis, MO, USA, 26-30 March 2006; pp. 2289-2310.

34. Henke, S.; Karstädt, D.; Möllmann, K.P.; Pinno, F.; Vollmer, M. Identification and suppression of thermal reflections in infrared thermal imaging. Proc. Inframation 2004, 5, 287-298.

35. Noble, T.L.; Lottermoser, B.G. Modified abrasion $\mathrm{pH}$ and NAGpH testing of minerals. In Environmental Indicators in Metal Mining; Lottermoser, B., Ed.; Springer International Publishing: Berlin/Heidelberg, Germany, 2017; pp. 211-220, ISBN 978-3-319-42729-4.

36. Kononov, V.A. Infrared Thermography of Loose Hangingwalls; CSIR: Pretoria, South Africa, 2002; p. 102.

37. Vraetz, T.; Baltes, R.; Fietz, N.; Nienhaus, K. Acoustic emission technology and thermal imaging for material flow characterization in mining. Min. Rep. 2017, 153, 461-467.

38. Zhai, X.; Wu, S.; Wang, K.; Drebenstedt, C.; Zhao, J. Environment influences and extinguish technology of spontaneous combustion of coal gangue heap of Baijigou coal mine in China. Energy Procedia 2017, 136, 66-72. [CrossRef]

39. Fierro, V.; Miranda, J.L.; Romero, C.; Andrés, J.M.; Pierrot, A.; Gómez-Landesa, E.; Arriaga, A.; Schmal, D. Use of infrared thermography for the evaluation of heat losses during coal storage. Fuel Process. Technol. 1999, 60, 213-229. [CrossRef]

40. Carpentier, O.; Defer, D.; Antczak, E.; Duthoit, B. The use of infrared thermographic and GPS topographic surveys to monitor spontaneous combustion of coal tips. Appl. Therm. Eng. 2005, 25, 2677-2686. [CrossRef]

41. Liu, H.; Wu, C. A new approach to detect fire source underground mine for preventing spontaneous combustion of sulfide ores. Procedia Eng. 2010, 7, 318-326. [CrossRef]

42. Mishra, R.K.; Bahuguna, P.P.; Singh, V.K. Detection of coal mine fire in jharia coal field using Landsat-7 ETM+ data. Int. J. Coal Geol. 2011, 86, 73-78. [CrossRef]

43. Hu, Z.; Xia, Q. An integrated methodology for monitoring spontaneous combustion of coal waste dumps based on surface temperature detection. Appl. Therm. Eng. 2017, 122, 27-38. [CrossRef]

44. Tomescu, C.; Prodan, M.; Vatavu, N.; Chiuzan, E. Monitoring the work environment using thermal imaging cameras in order to prevent the self-ignition of coal. Environ. Eng. Manag. J. 2017, 16, 1389-1393. [CrossRef]

45. Joshi, P.K.; Punia, A. Thermal infrared imaging to identify surface mines. Mine Water Environ. 2019, 38, 700-704. [CrossRef]

46. Liu, H.; Wu, C.; Shi, Y. Locating method of fire source for spontaneous combustion of sulfide ores. J. Cent. South Univ. Technol. 2011, 18, 1034-1040. [CrossRef]

47. Ghosh, A.; Sharma, A.K.; Nayak, B.; Sagar, S.P. Infrared thermography: An approach for iron ore gradation. Miner. Eng. 2014, 62, 85-90. [CrossRef]

48. Shannon, H.R.; Sigda, J.M.; Van Dam, R.L.; Hendrickx, J.M.H.; McLemore, V.T. Thermal camera imaging of rock piles at the questa molybdenum mine, questa, New Mexico. JASMR 2005, 2005, 1015-1028. [CrossRef]

49. Stylianou, M.; Tsiftes, K.; Gavriel, I.; Kostarelos, K.; Demetriou, C.; Papaioannou, A. Environmental impacts of abandoned sulphide mines -the example of mathiatis mine in cyprus. In Proceedings of the SYMBIOSIS International Conference, Athens, Greece, 19-21 June 2014; p. 7.

50. Garrels, R.M.; Thompson, M.E. Oxidation of pyrite by iron sulfate solutions. Amer. J. Sci. 1960, 258, 57-67.

51. Singer, P.C.; Stumm, W. Acidic mine drainage: The rate-determining step. Science 1970, 167, 1121-1123. [CrossRef] [PubMed]

52. Haynes, W.M. CRC Handbook of Chemistry and Physics: A Ready-Reference Book of Chemical and Physical Data, 97th ed.; CRC Press: Boca Raton, FL, USA, 2017; ISBN 978-1-4987-5428-6. 
53. Lefebvre, R.; Gelinas, P.; Isabel, D. Heat Transfer during Acid Mine Drainage Production in a Waste Rock Dump, La Mine Doyon (Québec); University Laval: Québec QC, Canada, 1997; p. 106.

54. Zhang, Y.; Li, Q.; Liu, X.; Xu, B.; Yang, Y.; Jiang, T. A thermodynamic analysis on the roasting of pyrite. Minerals 2019, 9, 220. [CrossRef]

55. Dunn, J.G. The oxidation of sulphide minerals. Thermochim. Acta 1997, 300, 127-139. [CrossRef]

56. Pérez-Tello, M.; Sohn, H.Y.; Löttiger, J. Determination of the oxidation characteristics of solid copper matte particles by differential scanning calorimetry and thermogravimetric analysis. Min. Metall. Explor. 1999, 16, 1-7. [CrossRef]

57. Wang, H.; Pring, A.; Xie, Y.; Ngothai, Y.; O'neill, B. Phase evolution and kinetics of the oxidation of monosulfide solid solution under isothermal conditions. Thermochim. Acta 2005, 427, 13-25. [CrossRef]

58. Deore, S. Oxide melt solution calorimetry of sulfides: Enthalpy of formation of sphalerite, galena, greenockite, and hawleyite. Am. Mineral. 2006, 91, 400-403. [CrossRef]

59. Pérez-Fontes, S.E.; Pérez-Tello, M.; Prieto-López, L.O.; Brown, F.; Castillón-Barraza, F. Thermoanalytical study on the oxidation of sulfide minerals at high temperatures. Min. Metall. Explor. 2007, 24, 275-283. [CrossRef]

60. Bylina, I.; Trevani, L.; Mojumdar, S.C.; Tremaine, P.; Papangelakis, V.G. Measurement of reaction enthalpy during pressure oxidation of sulphide minerals. J. Therm. Anal. Calorim. 2009, 96, 117-124. [CrossRef]

61. Iliyas, A.; Hawboldt, K.; Khan, F. Thermal stability investigation of sulfide minerals in DSC. J. Hazard. Mater. 2010, 178, 814-822. [CrossRef]

62. Iliyas, A.; Hawboldt, K.; Khan, F. Kinetics and safety analysis of sulfide mineral self-heating: Part 1. Effect of mineralogy. J. Therm. Anal. Calorim. 2011, 106, 53-61. [CrossRef]

63. Bylina, I.V.; Mojumdar, S.C.; Papangelakis, V.G. Effect of storage time on the pressure oxidation enthalpy of pyrite. J. Therm. Anal. Calorim. 2012, 108, 829-835. [CrossRef]

64. Yang, F.; Wu, C.; Li, Z. Spontaneous combustion tendency of fresh and pre-oxidized sulfide ores. J. Cent. South Univ. 2014, 21, 715-719. [CrossRef]

65. Liu, H.; Xiang, C.; Hong, R.; Song, Y.; Jin, K.; Zhu, K.; Yang, C.; Lv, C. Thermal behavior and kinetics of sulfide concentrates. Therm. Sci. 2019, 23, 2801-2811. [CrossRef]

66. Teong, S.P.; Li, X.; Zhang, Y. Hydrogen peroxide as an oxidant in biomass-to-chemical processes of industrial interest. Green. Chem. 2019, 21, 5753-5780. [CrossRef]

67. Golchoubian, H.; Hosseinpoor, F. Effective oxidation of sulfides to sulfoxides with hydrogen peroxide under transition-metal-free conditions. Molecules 2007, 12, 304-311. [CrossRef]

68. Lin, S.-S.; Gurol, M.D. Catalytic Decomposition of hydrogen peroxide on iron oxide: Kinetics, mechanism, and implications. Environ. Sci. Technol. 1998, 32, 1417-1423. [CrossRef]

69. De Laat, J.; Gallard, H. Catalytic decomposition of hydrogen peroxide by Fe(III) in homogeneous aqueous solution: Mechanism and kinetic modeling. Environ. Sci. Technol. 1999, 33, 2726-2732. [CrossRef]

70. Huang, H.-H.; Lu, M.-C.; Chen, J.-N. Catalytic decomposition of hydrogen peroxide and 2-chlorophenol with iron oxides. Water Res. 2001, 35, 2291-2299. [CrossRef]

71. Hermanek, M.; Zboril, R.; Medrik, I.; Pechousek, J.; Gregor, C. Catalytic efficiency of iron(III) oxides in decomposition of hydrogen peroxide: Competition between the surface area and crystallinity of nanoparticles. J. Am. Chem. Soc. 2007, 129, 10929-10936. [CrossRef] [PubMed]

72. Stewart, W.A.; Miller, S.D.; Smart, R.; Gerson, A.R.; Thomas, J.E.; Skinner, W.M.; Levay, G.; Schumann, R. Evaluation of the net acid generation (NAG) test for Assessing the acid generation capacity of sulphide minerals. In Proceedings of the 6th ICARD, Queensland, Australia, 14-17 July 2003; pp. 617-625.

73. Evangelou, V.P. Pyrite Oxidation and its Control: Solution Chemistry, Surface Chemistry, Acid Mine Drainage (AMD), Molecular Oxidation Mechanisms, Microbial Role, Kinetics, Control, Ameliorates and Limitations, Microencapsulation, 1st ed.; CRC Press: Boca Raton, FL, USA, 1995; ISBN 978-0-203-74164-1.

74. Elberling, B. Environmental controls of the seasonal variation in oxygen uptake in sulfidic tailings deposited in a permafrost-affected area. Water Resour. Res. 2001, 37, 99-107. [CrossRef]

75. Elberling, B. Temperature and oxygen control on pyrite oxidation in frozen mine tailings. Cold Reg. Sci. Technol. 2005, 41, 121-133. [CrossRef]

76. Antonijević, M.M.; Dimitrijević, M.; Janković, Z. Leaching of pyrite with hydrogen peroxide in sulphuric acid. Hydrometallurgy 1997, 46, 71-83. [CrossRef] 
77. Chirita, P. Pyrite oxidation by hydrogen peroxide in phosphoric acid solutions. Eur. J. Miner. Process. Environ. 2004, 4, 203-209.

78. Liu, W.; Xu, L.; Li, X.; Shen, C.; Rashid, S.; Wen, Y.; Liu, W.; Wu, X. High-dispersive FeS 2 on graphene oxide for effective degradation of 4-chlorophenol. RSC Adv. 2015, 5, 2449-2456. [CrossRef]

79. Lefticariu, L.; Schimmelmann, A.; Pratt, L.M.; Ripley, E.M. Oxygen isotope partitioning during oxidation of pyrite by $\mathrm{H} 2 \mathrm{O} 2$ and its dependence on temperature. Geochim. Cosmochim. Acta 2007, 71, 5072-5088. [CrossRef]

80. Dold, B.; Fontboté, L. A mineralogical and geochemical study of element mobility in sulfide mine tailings of Fe oxide $\mathrm{Cu}-\mathrm{Au}$ deposits from the Punta del Cobre belt, northern Chile. Chem. Geol. 2002, 189, 135-163. [CrossRef]

81. Vaughan, D.J.; Becker, U.; Wright, K. Sulphide mineral surfaces: Theory and experiment. Int. J. Miner. Process. 1997, 51, 1-14. [CrossRef]

82. Rimstidt, J.D.; Chermak, J.A.; Gagen, P.M. Rates of reaction of galena, sphalerite, chalcopyrite, and arsenopyrite with $\mathrm{Fe}(\mathrm{III})$ in acidic solutions. In Environmental Geochemistry of Sulfide Oxidation; ACS Symposium Series; Alpers, C.N., Blowes, D.W., Eds.; American Chemical Society: Washington, DC, USA, 1993; Volume 550, pp. 2-13, ISBN 978-0-8412-2772-9.

83. Chopard, A.; Benzaazoua, M.; Plante, B.; Bouzahzah, H.; Marion, P. Kinetic tests to evaluate the relative oxidation rates of various sulfides and sulfosalts. In Proceedings of the 10th ICARD, Santiago, Chile, 21-24 April 2015; pp. 1-10.

84. Mok, W.M.; Wai, C.M. Mobilization of arsenic in contaminated river waters. In Arsenic in the Environment. Part 1 Cycling and Characterization; Nriagu, J.O., Ed.; John Wiley Interscience: New York, NY, USA, 1994; pp. 99-108.

85. Dold, B. Basic concepts in environmental geochemistry of sulfidic mine-waste management. In Waste Management; Kumar, S., Ed.; IntechOpen: Rijeka, Croatia, 2010; pp. 173-198, ISBN 978-953-7619-84-8.

86. Hoefer Chemie GmbH Safety Data Sheet According to Regulation (EC) No 1907/2006. 2012, 1-10. Available online: https://www.hoefer-chemie.de/upload/SDB/Wasserstoffperoxid11.9.pdf (accessed on 2 October 2020).

87. Steger, H.F. Oxidation of sulfide minerals. Chem. Geol. 1982, 35, 281-295. [CrossRef]

88. Lottermoser, B. Acid producing reactions. In Mine Wastes; Lottermoser, B.G., Ed.; Springer: Berlin/Heidelberg, Germany, 2010; Volume 3, pp. 46-60, ISBN 978-3-642-12418-1.

89. Yazıc1, E.Y.; Deveci, H. Factors Affecting decomposition of hydrogen peroxide. In Proceedings of the XIIth international mineral processing symposium, Cappadocia-Nevsehir, Turkey, 6-8 October 2010; pp. 609-616.

90. Lengke, M.F.; Tempel, R.N. Geochemical modeling of arsenic sulfide oxidation kinetics in a mining environment. Geochim. Cosmochim. Acta 2005, 69, 341-356. [CrossRef]

91. Evangelou, V.P.; Zhang, Y.L. A review: Pyrite oxidation mechanisms and acid mine drainage prevention. Crit. Rev. Environ. Sci. Technol. 1995, 25, 141-199. [CrossRef]

92. Rosso, K.M. Reactivity of sulfide mineral surfaces. Rev. Mineral. Geochem. 2006, 61, 557-607. [CrossRef]

93. Barnes, A.; Bowell, R.J.; Warrender, R.; Sapsford, D.J.; Sexsmith, K.; Charles, J.; Declercq, J.; Santonastaso, M.; Dey, M. Comparison between long-Term humidity cell testing and static net acid generation (NAG) tests: Potential for NAG use in preliminary mine site water quality predictions. In Proceedings of the 10th ICARD, Santiago, Chile, 21-24 April 2015; pp. 1-10.

94. Weber, P.A.; Stewart, W.A.; Skinner, W.M.; Weisener, C.G.; Thomas, J.E.; Smart, R.S.C. Geochemical effects of oxidation products and framboidal pyrite oxidation in acid mine drainage prediction techniques. Appl. Geochem. 2004, 19, 1953-1974. [CrossRef]

95. Kwong, Y.T.J. Prediction and Prevention of Acid Rock Drainage from a Geological and Mineralogical Perspective; MEND Project 1.32.1. National Hydrology Research Institute: Saskatoon, SK, Canada, 1993.

Publisher's Note: MDPI stays neutral with regard to jurisdictional claims in published maps and institutional affiliations. 